\title{
Transcriptome Analysis of Intestinal Dysfunction in Newborn Piglets with Intrauterine Growth Restriction and Improve their Performance by Dimethylglycine Sodium Salt Supplementation after Weaning
}

\section{Kaiwen Bai}

Nanjing Agricultural University - Weigang Campus: Nanjing Agricultural University

Luyi Jiang

Zhejiang University - Zijingang Campus: Zhejiang University

\section{Qiming Li}

Nanjing Agricultural University - Weigang Campus: Nanjing Agricultural University

Jingfei Zhang

Nanjing Agricultural University - Weigang Campus: Nanjing Agricultural University

Lili Zhang

Nanjing Agricultural University - Weigang Campus: Nanjing Agricultural University

Tian Wang ( $\square$ tianwangnjau@163.com)

Nanjing Agricultural University https://orcid.org/0000-0002-9038-5009

\section{Research Article}

Keywords: Intrauterine growth restriction, piglets, jejunum, redox status, mitochondrial function, dimethylglycine sodium salt

Posted Date: April 29th, 2021

DOI: https://doi.org/10.21203/rs.3.rs-451620/v1

License: (c) (i) This work is licensed under a Creative Commons Attribution 4.0 International License.

Read Full License 


\section{Abstract \\ Background}

Few studies are available on the mechanism of intestinal dysfunction in newborn piglets with intrauterine growth restriction (IUGR). This work aimed to study the mechanism of jejunum dysfunction in IUGR newborn piglets through RNA-seq and improve their performance by dimethylglycine sodium salt (DMG$\mathrm{Na}$ ) supplementation after weaning.

\section{Methods}

In total, 13 normal birth weight (NBW) newborn piglets and 23 IUGR newborn piglets were obtained. Among them, 3 NBW and 3 IUGR newborn piglets were selected and stunned by electric shock after birth without suckling and collected the jejunum samples for RNA-sEq. After weaning at 21 days, they were randomly assigned to 3 groups $(n=10)$ : NBW weaned piglets fed with common basal diets $(N)$; IUGR weaned piglets fed with common basal diets (I); IUGR weaned piglets fed with common basal diets plus $0.1 \%$ DMG-Na (ID). All piglets are slaughtered at 49 days of age to collect serum and jejunum samples.

\section{Results}

The hub genes, including ATP8, C11orf86, CDKN1C, DDX58. HPX, INHBB, LECT2, ND1, NFIX, PRDM5, PSD3, SCD, and ZNF770, were found from the data analyzed by RNA-seq and WGCNA. Interestingly, we found ATP8 was the most significantly changed gene, which was crucial in maintaining mitochondrial function. After weaning, the growth performance of ID group was improved $(P<0.05)$ compared to that in I group. Jejunum histological morphology and its sub-organelle ultrastructure, serum immunoglobulin, jejunum slgA level, and jejunum digestive enzyme activity were improved $(P<0.05)$ in ID group compared to those in I group. The redox status of serum, jejunum and its mitochondrial, as well as jejunum redox status-related and mitochondrial function-related gene expression level and protein content were improved $(P<0.05)$ in ID group in comparison to those in I group.

\section{Conclusion}

The activity of the SIRT1/PGC1a pathway was inhibited in the IUGR weaned piglets, which in turn leads to damage to their redox status and jejunum structure and function, and finally lowers their performance. The IUGR weaned piglets activate the SIRT1/PGC1a pathway by taking in the antioxidant substance like DMG-Na, thereby improving their unfavorable body state.

\section{Background}


Intrauterine growth restriction (IUGR), defined as small-sized individuals in gestational age with weight below the 10th -centile or the population mean minus 2 standard deviations of a population-based nomogram, is an important problem in animal husbandry [1, 2]. IUGR showed a permanent stunting effect on postnatal growth and the efficiency of nutrient utilization in offspring and impairs long-term health [3, 4]. The gastrointestinal tract is crucial in the digestion, absorption, and metabolism of dietary nutrients [2]. However, little is known about the postnatal effects of IUGR on the structure and function of the small intestine. This point appears to be important because the small intestine is involved in the first steps of postnatal immune system maturation, body protection against food allergens and environmental microorganisms, and nutrient assimilation. After birth, altered gastrointestinal functions may lead to diseases, and slow gastrointestinal growth may therefore contribute to slow postnatal growth rates in neonates with IUGR, and altered redox status of the gastrointestinal tract may compromise the health of neonates with IUGR throughout the postnatal stage and later on in adulthood [2,5]. Oxidative damage caused by an imbalance between the antioxidant system and free radical generation system leads to an increase in reactive oxygen species (ROS) level, which mediates tissue and mitochondrial damage. Mitochondria are the principal energy sources of cells that convert nutrients into energy through cellular respiration and compromised mitochondrial function has been linked to numerous diseases, like IUGR [6, 7].

Dimethylglycine sodium salt (DMG-Na) could improve body immunity and relieve oxidative damage by scavenging free radicals generated excessively [8]. DMG-Na is similar to choline and betaine and could improve redox status by acting as an important material for the synthesis of glutathione [9]. Previous studies found that DMG-Na could relieve oxidative damage and improve offspring performance $[9,10]$. It has been reported that DMG-Na not only improved the utilization of oxygen to protect the body from an excess of free radicals but also enhanced the immune response of individuals [11]. In this work, the ATP8 gene, analyzed by RNA-seq and Weighted gene co-expression network analysis (WGCNA), was found to be important in maintaining mitochondrial function. Meanwhile, decreased SIRT1 activity could damage the redox status and suppress the mitochondrial function of jejunum in IUGR weaned piglets via its substrate PGC1a. We also provide a novel insight into the effects of DMG-Na on jejunum redox status and mitochondrial function of IUGR weaned piglets via the SIRT1/PGC1a pathway.

\section{Materials And Methods}

\section{Animals}

In this study, thirteen normal birth weight (NBW) newborn piglets $(1.53 \pm 0.04 \mathrm{~kg})$ and twenty-three IUGR newborn piglets $(0.76 \pm 0.06 \mathrm{~kg})$ from sows (Duroc $\times$ (Landrace $\times$ Yorkshire) ) were obtained from Yangzhou Fangling Agricultural and Pastoral Co., Ltd. (Jiangsu, China) [12]. Sows were of similar birth order and fed with the same gestating diet, which met NRC (2012) nutrient requirements. Among them, three NBW newborn piglets (NBW1, NBW2, NBW3) and three IUGR newborn piglets (IUGR1, IUGR2, IUGR3) were stunned by electric shock and slaughtered by jugular bloodletting within two hours after birth without suckling, and collected the jejunum samples for transcriptome study. All the other newborn 
piglets were allowed to suckle the sow naturally up to 21 days of weaning age and then randomly allocated to three treatments with ten replicates per treatment: $\mathrm{N}=$ NBW weaned piglets fed with common basal diets (Table S1); I = IUGR weaned piglets fed with common basal diets; ID = IUGR weaned piglets fed with common basal diets plus 0.1\% DMG-Na (DMG-Na was obtained from Qilu Sheng Hua Pharmaceutical Co., Ltd., Shandong, China). All procedures were approved by the Institutional Animal Care and Use Committee of Nanjing Agricultural University, China. Piglets were housed individually in plastic floored pens $(1 \mathrm{~m} \times 0.6 \mathrm{~m})$ at an ambient temperature of $28^{\circ} \mathrm{C}$ in an environmentally controlled room and had free access to water. At 49 days of age, the piglets were weighed after feed deprivation for $12 \mathrm{~h}$ to calculate average daily weight gain (ADG), and feed consumption was recorded by using replicates to calculate average daily feed intake (ADFI) and feed conversion ratio (G:F). Then, blood and jejunum samples were obtained and stored at $-80^{\circ} \mathrm{C}$ for further study.

\section{Construction of mRNA library and bioinformatic analysis}

Total RNA was isolated from the jejunum samples using Trizol (Invitrogen, Carlsbad, CA, USA) according to manual instruction [13]. The double-stranded and single-stranded DNA in total RNA was removed by DNase I digesting, and RNase $\mathrm{H}$ or Ribo-Zero method (Illumina, USA) was used to remove the rRNA, and then purified mRNA was fragmented into small pieces with fragment buffer. The first-strand and secondstrand cDNA was generated in First-Strand Reaction System by PCR. The reaction product was purified by magnetic beads, afterwards, A-Tailing Mix and RNA Index Adapters were added by incubating to carry out end repair. The cDNA fragments with adapters were amplified by PCR, and the products were purified by Ampure XP Beads. The library was validating on the Agilent Technologies 2100 bioanalyzer for quality control. The double-stranded PCR products above were heated denatured and circularized by the splint oligo sequence. The single-strand circle DNA (ssCir DNA) was formatted as the final library. The final library was amplified with phi29 (Thermo Fisher Scientific, MA, USA) to make DNA nanoball (DNB) which had more than 300 copies of one molecular, DNBs were loaded into the patterned nanoarray and single end 50 bases reads were generated on BGISEQ500 platform (BGI-Shenzhen, China).

The sequencing data was filtered with SOAPnuke (v1.5.2) by removing reads of sequencing adapter, reads of low-quality base ratio more than $20 \%$, reads of unknown base (' $N$ ' base) ratio more than $5 \%$, afterward clean reads were stored in FASTQ format. The clean reads were mapped to the Sus_scrofa (NCBI_GCF_000003025.6_Sscrofa11.1) using HISAT2 (v2.0.4). Bowtie2 (v2.2.5) was applied to align the clean reads to the Sscrofa11.1, then the expression level of genes was calculated by RSEM (v1.2.12). The heatmap was drawn by pheatmap (v1.0.8) according to the gene expression in different samples. Essentially, differential expression analysis was performed using the DESeq2 (v1.4.5) with a q value lower than 0.05. To take an insight into the change of phenotype, Gene Ontology (GO) (http://geneontology.org/) and Kyoto Encyclopedia of Genes (KEGG) (https://www.kegg.jp/) enrichment analysis of annotated different expressed gene was performed by Phyper (https://en.wikipedia.org/wiki/Hypergeometric_distribution.) based on Hypergeometric test. The significant levels of terms and pathways using the corrected $P$-value $<0.05$ as a threshold to find 
significantly enriched KEGG terms in the input list of differential expression genes, comparing them to the whole genome background. The calculation formula of the $P$-value was as follows:

$$
P=1-\sum_{i=0}^{m-1}\left(\frac{\left(\frac{M}{i}\right)\left(\frac{N-M}{n-i}\right)}{\frac{N}{n}}\right)
$$

$\mathrm{N}$ represented the number of KEGG annotated genes in jejunum samples, $\mathrm{n}$ represented the number of differentially expressed genes in N, M represented the number of particular KEGG annotated genes in a genome, and $m$ represented the number of particular KEGG annotated genes expressed differentially in M. After correction for multiple testing, we chose pathways with a $P$-value $<0.05$ to represent those significantly enriched in different expression genes.

\section{Weighted gene co-expression network analysis (WGCNA)}

The WGCNA R package [14] was used in order to assess the relationships between clusters of coexpressed genes and phenotypes related to IUGR. At first, the network was constructed grouping the functionally correlated genes into modules based on the pairwise correlations, corresponding to their similar gene expression level. To construct the network of co-expressed genes and to cluster genes that exhibit similar expression patterns, the WGCNA package built an adjacency matrix in which the nodes of the network correspond to gene expression profiles, and edges between genes are determined by the pairwise correlations between gene expressions, calculated using the Pearson's correlation. First, it was necessary to find an optimal soft-thresholding power to transform the co-expression similarity into adjacency. Thus, after performing the analysis of network topology for several soft-thresholding parameters, power 12 was chosen as the soft-thresholding power to reach a scale-free topology index. Then, the gene network was constructed using the blockwiseModules function, and modules of coexpressed genes were detected by using hierarchical clustering. In the blockwiseModules function, we have chosen 30 for the minimum module size. Once identified groups of genes characterized by a similar trend of expression profile, it was necessary to detect modules that were most significantly related to the measured traits of interest. In this regard, the association values between modules and traits were quantified using Pearson's correlation. In particular, to identify the module-trait relationship, the WGCNA package determined the expression value of each module using the principal component analysis. Indeed, the ME can be considered representative for the gene expression profile of the corresponding module. This approach allowed us to calculate Pearson's correlations between each module eigengene and trait, and thus to identify the module-trait relationship. The most significantly correlated with the macro-trait $(P<0.01)$ were characterized by an absolute value of module-trait correlation higher than 0.8 . Differential expression analysis was performed using the DEGseq, q value $\leq 0.01$, and the absolute value of Log2Ratio $\geq 1$ as the default threshold to judge the significance of expression difference. To annotate gene functions, all target genes were aligned against the GO and KEGG database. GO enrichment analysis and KEGG enrichment analysis of target genes were performed using phyper [15], a function of 
R. The $P$-value was corrected using the Bonferroni method, and a corrected $P$-value $\leq 0.05$ was taken as a threshold. GO terms or KEGG terms fulfilling this condition were defined as significantly enriched terms.

\section{Histological study}

Jejunum samples were fixed in $1 \%(\mathrm{v} / \mathrm{v})$ glutaraldehyde solution and stored in the same solution at $48{ }^{\circ} \mathrm{C}$ until processed. After postfixation for $5 \mathrm{~min}$ in $2 \%(\mathrm{w} / \mathrm{v})$ osmium tetroxide, samples were processed conventionally for transmission electron microscopy visualization and examined in a Philips 420 transmission electron microscope at $80 \mathrm{kV}$ [2].

Jejunum samples fixed in $4 \%$ buffered formaldehyde were dried up using a graded series of xylene and ethanol, after which they were embedded in paraffin for histological processing. The samples (8 microns in size) were then deparaffinized using xylene and rehydrated with graded dilutions of ethanol. The slides were stained with hematoxylin-eosin (HE). Ten slides for each sample (middle site of samples) were prepared, and the images were acquired using an optical binocular microscope. Values of villus length (L), crypt depth, and villus width (W) were measured five times from different villus and crypts per slide [2]. Villus area (S) was calculated using the following formula:

$$
\mathrm{S}=\pi \times\left(\frac{\mathrm{W}}{2}\right) \sqrt{\left(\frac{\mathrm{W}}{2}\right)^{2}+\mathrm{L}^{2}}
$$

\section{Serum immunoglobulin and jejunum slgA level}

Serum IgA, IgG, and IgM concentrations were measured with corresponding ELISA assay kits (Nanjing Jiancheng Bioengineering Institute, Nanjing, Jiangsu, China) according to the previously described method [16].

Jejunum samples were homogenized in $0.9 \%$ sodium chloride buffer on ice and then centrifuged at 2,800 $\times g$ at $4{ }^{\circ} \mathrm{C}$ for $15 \mathrm{~min}$. The supernatant was used to measure the slgA concentration with an ELISA assay kit (Nanjing Jiancheng Bioengineering Institute, Nanjing, Jiangsu, China) according to the method described by Hu et al [17].

\section{Digestive enzyme activity}

Jejunum samples were homogenized in $0.9 \%$ sodium chloride buffer on ice and then centrifuged at 2,800 $\times g$ at $4{ }^{\circ} \mathrm{C}$ for $15 \mathrm{~min}$. The supernatant was used to measure the jejunum sucrase, maltase, and lactase level with corresponding assay kits (Nanjing Jiancheng Bioengineering Institute, Nanjing, Jiangsu, China).

Jejunum samples were homogenized in $0.9 \%$ sodium chloride buffer on ice and then centrifuged at 2,500 $\times g$ at $4{ }^{\circ} \mathrm{C}$ for $10 \mathrm{~min}$. The supernatant was used to measure the intestinal amylase, lipase, and chymotrypsin level with corresponding assay kits (Nanjing Jiancheng Bioengineering Institute, Nanjing, Jiangsu, China). 


\section{Redox status}

Jejunum samples were homogenized in $0.9 \%$ sodium chloride solution on ice and centrifuged at 3,500 $\times$ $g$ for $15 \mathrm{~min}$ at $4{ }^{\circ} \mathrm{C}$. Serum and supernatant of tissue homogenate solution was separated to measure the level of superoxide dismutase (SOD) [18], glutathione peroxidase (GSH-Px) [19], glutathione (GSH) [20], and malondialdehyde (MDA) [21], according to the method described previously with corresponding assay kits (Nanjing Jiancheng Bioengineering Institute, Nanjing, Jiangsu, China). Protein content was determined with a bicinchoninic acid (BCA) protein assay kit (Nanjing Jiancheng Bioengineering Institute, Nanjing, Jiangsu, China).

\section{Mitochondrial redox status}

Jejunum mitochondria were originally described by Roediger and Truelove [22]. The level of protein content, manganese superoxide dismutase (MnSOD) [18], glutathione pe oxidase (GPx) [19], GSH [20], Yglutamylcysteine ligase ( $\mathrm{Y}-\mathrm{GCL})$, protein oxidation (PC) [23], 8-hydroxy-2-deoxyguanosine (8-OHdG) [24], ROS [25], mitochondrial membrane potential (MMP) [25], cell apoptosis [25], and mitochondrial DNA (mtDNA) [26] were calculated according to the method described respectively with corresponding assay kits (Nanjing Jiancheng Bioengineering Institute, Nanjing, Jiangsu, China).

\section{Quantitative real-time PCR}

Quantitative real-time PCR (qPCR) was performed as described by Mohamed et al. [13]. Total RNA was obtained from jejunum samples using Trizol Reagent (TaKaRa, Dalian, China) and then reversetranscribed using a commercial kit (Perfect Real Time, SYBR@ ${ }^{@}$ PrimeScript ${ }^{\mathrm{TM}}$, TaKaRa) following the instructions of the manufacturer. The mRNA expression levels of specific genes were quantified via realtime PCR, using SYBR ${ }^{@}$ Premix Ex Taq ${ }^{\mathrm{TM}}$ II (Tli RNaseH Plus) and an ABI 7300 Fast Real-Time PCR detection system (Applied Biosystems, Foster City, CA). The SYBR Green PCR reaction mixture consisted of $10 \mu \mathrm{L}$ SYBR@Premix Ex Taq (2X), $0.4 \mu$ l of the forward and reverse primers, $0.4 \mu \mathrm{L}$ of ROX reference dye (50X), $6.8 \mu \mathrm{L}$ of $\mathrm{ddH}_{2} \mathrm{O}$, and $2 \mu \mathrm{L}$ of cDNA template. Each sample was amplified in triplicate. The foldexpression of each gene was calculated according to the $2^{-\Delta \Delta C t}$ method [13], in which the $\beta$-actin gene was used as an internal standard. The primer sequences used are given in Table S2.

\section{Western blotting}

Antibodies against related proteins were purchased from Cell Signaling Technology (Danvers, MA, USA). The protein content of samples was measured using the BCA Protein Assay Kit (Beyotime, Jiangsu, China). For western blotting analysis, $50 \mathrm{\mu g}$ of protein from each jejunum sample was analyzed through sodium dodecyl sulfate-polyacrylamide gel electrophoresis (SDS-PAGE). After SDS-PAGE, proteins were separated and transferred to polyvinylidene difluoride membranes. Membranes were blocked with blocking buffer ( $5 \%$ nonfat dry milk) for $12 \mathrm{~h}$ at $4{ }^{\circ} \mathrm{C}$. Membranes were probed with appropriate primary and secondary antibodies (horseradish peroxidase-conjugated goat antirabbit immunoglobulin G, Cell Signaling Technology; 1:10,000 dilution in 1\% milk). Blots were detected using enhanced 
chemiluminescence reagents (ECL-Kit, Beyotime, Jiangsu, China) followed by autoradiography. Photographs of membranes were taken using the Luminescent Image Analyzer LAS-4000 system (Fujifilm Co.) and quantified with ImageJ 1.42q software (NIH, Bethesda, MD, USA).

\section{Statistical Analysis}

Data are presented as the Mean \pm SEM and were statistically analyzed by one-way analysis of variance (ANOVA) procedure of Statistical Analysis System (version 9.1; SAS Institute, Inc., Cary, Nc, USA). This was followed by Tukey's test when significant differences were found $(P<0.05)$. The significance was defined as $P<0.05$.

\section{Results}

In order to identify gene differentiation of jejunum between NBW newborn piglets and IUGR newborn piglets, NBW group (NBW1, NBW2, NBW3) and IUGR group (IUGR1, IUGR2, IUGR3) were constructed with total RNA and subjected to Illumina deep sequencing. Overviews of the sequencing and assembly results were shown in Table S3. After discarding the low-quality of raw reads, 276,210,270 clean reads remained. All the 19.935 assembled genes were referenced against Swiss-Prot, Nr, Pfam, KEGG, KOG, and GO databases, with the number of genes 12.630 (63.36\%), 18.172 (91.16\%), 16.602 (83.28\%), 6.314 (31.67\%), 10.976 (55.06\%), and 7.487 (37.56\%), respectively (Table S4). To explore the molecular mechanisms of jejunum in response to IUGR, RPKM method analysis was performed to determine the differential expression genes. We found that 14 mRNAs were up-regulated $(P<0.05)$, while 25 genes were down-regulated $(P<0.05)$ in response to IUGR (Table S5). We then made a hierarchical clustering of the different expression genes based on the six samples' $\log 10(\mathrm{RPKM}+1)$, with the results indicating that the samples could be sorted into two distinct groups (Fig. 1A). Overall, undergoing IUGR had a significant impact on the global gene expression profile of jejunum in newborn piglets.

According to the GO classification system, genes involved in the "cellular process" ( 25 genes) and "metabolic process" (21 genes) were notably represented in the biological process category. Among the cellular components, "cell" (21 genes) was the most commonly represented, followed by "cell part" (21 genes) and "organelle" (15 genes). In the category of molecular function, a significant proportion of clusters were assigned to "binding" (21 genes) and "catalytic activity" (15 genes) (Fig S1). To classify orthologous gene products, the different expression genes were subdivided into 25 KOG classifications. Among them, the cluster of "General function prediction only" (10 genes) represented the largest group, followed by "Signal transduction mechanisms" (9 genes) and "Transcription" (4 genes) (Fig S2). The Kyoto Encyclopedia of Genes and Genomes (KEGG) classification was found for the differential expression genes that were further classified into 6 biochemical pathways, including Cellular Processes (5 genes), Environmental Information Processing (17 genes), Genetic Information Processing (2 genes), Human Diseases (31 genes), Metabolism (10 genes), and Organismal Systems (50 genes), respectively

(Fig S3). 
By performing the KEGG pathway analyses, a total of 15 pathways that changed significantly $(P<0.05)$ in the IUGR newborn piglets in comparison to the NBW newborn piglets were identified (Fig. 1B). Among these pathways, "Bile secretion", "Pancreatic secretion", and "Salivary secretion" are included in the "Digestive system" sub-class. "Regulation of lipolysis in adipocytes" and "PPAR signaling pathway" are included in the "Endocrine system" sub-class. In addition, some important subclasses have also been significantly enriched, including "Signal transduction", "Nervous system", "Metabolism of cofactors and vitamins", "Substance dependence”, "Membrane transport", "Nervous system”, "Immune system”, "Folding, sorting and degradation", "Environmental adaptation", and "Endocrine system". These results imply that the genes involved in these pathways may play crucial roles in newborn piglets' jejunum in response to IUGR.

As a result of network construction, the WGCNA analysis found 9 modules (power =12) (Fig S4), identified by a different color. The 1159 gene modules identified by WGCNA are shown by cluster dendrogram (Fig S5), in which the branches correspond to modules and each leaf in the branch represents one probe. The WGCNA R package allowed us to quantify correlation values between the genes of each module and the considered phenotypes, assessing in this way the module-trait association. In this regard, Fig. 1C shows the associations between modules and traits using a heatmap plot, which graphically represents Pearson's correlation coefficients measured between every single module and trait (Table S6). From the data, the module yellow $(P=0.05, r=0.81)$ exerted the most significantly correlated with the trait, which includes 254 genes. According to the $\mathrm{GO}$ classification system, 254 genes of the module yellow involved in "cellular process" (65 genes) and "single-organism process" (57 genes) were notably represented in the biological process category. Among the cellular components, "cell" (71 genes) and "cell part" (71 genes) were the most commonly represented, followed by "organelle" (50 genes). In the category of molecular function, a significant proportion of clusters were assigned to "binding" (73 genes) and "catalytic activity" (39 genes) (Fig S6). The KEGG classification was found for the 254 genes of MEyellow module that were further classified into 4 biochemical pathways (Fig S7). Cellular Processes (25 genes), Environmental Information Processing (59 genes), Human Diseases (58 genes), and Organismal Systems (118 genes), respectively. A total of 13 hub genes was obtained from co-analysis of RNA-seq and WGCNA (Table S7).

Effects of DMG-Na on the growth performance of IUGR weaned piglets were shown in Table 1. Compared with $\mathrm{N}$ group, I group showed lower $(P<0.05)$ ADG, ADFI, IBW, and FBW values. The ADG, G:F, and FBW values of ID group were improved $(P<0.05)$ compared to that of I group. 
Table 1

Effects of DMG-Na on growth performance of IUGR weaned piglets ${ }^{1}$

\begin{tabular}{|llll|}
\hline \multicolumn{3}{|c|}{ Treatment $^{2}$} & \\
\hline Item & & & \\
\hline ADG $(\mathrm{g})$ & $\mathrm{N}$ & $\mathrm{I}$ & $351.70 \pm 58.04^{\mathrm{a}}$ \\
\hline ADFI (g/d) & $333.35 \pm 37.65^{\mathrm{a}}$ & $283.53 \pm 31.29^{\mathrm{b}}$ & $546.42 \pm 37.39^{\mathrm{b}}$ \\
\hline G:F & $607.13 \pm 38.33^{\mathrm{a}}$ & $532.14 \pm 34.19^{\mathrm{b}}$ & $0.64 \pm 0.05^{\mathrm{a}}$ \\
\hline IBW $(\mathrm{kg})$ & $0.55 \pm 0.04^{\mathrm{b}}$ & $0.53 \pm 0.06^{\mathrm{b}}$ & $6.02 \pm 0.57^{\mathrm{b}}$ \\
\hline FBW $(\mathrm{kg})$ & $7.71 \pm 0.58^{\mathrm{a}}$ & $5.80 \pm 0.60^{\mathrm{b}}$ & $15.87 \pm 2.02^{\mathrm{b}}$ \\
\hline
\end{tabular}

${ }^{1}$ Values are expressed as Mean $\pm S E M, n=10$. Values in the same row with different superscripts were significantly different $(P<0.05)$.

${ }^{2} \mathrm{~N}$, NBW weaned piglets fed with common basal diets; I, IUGR weaned piglets fed with common basal diets; ID, IUGR weaned piglets fed with common basal diets plus $0.1 \%$ DMG-Na; NBW, normal birth weight; IUGR, intrauterine growth retardation.

${ }^{3} A D G$, average daily weight gain; $A D F I$, average daily feed intake; IBW, initial body weight; FBW, final body weight; G:F, weight gain: feed intake.

Effects of DMG-Na on jejunum villi, microvilli, and its structure of IUGR weaned piglets were revealed in Fig. 2. Compared with $\mathrm{N}$ group, jejunum villi of I group are more susceptible to oxidative damage, shorter, and with different lengths. Jejunum microvilli of I group were shorter and less frequent than those of $\mathrm{N}$ group. In addition, autophagosomes and mitochondrial swelling were observed in I group, and these features were not found in N group (Fig. 2A). The jejunum villi, internal microvilli, and internal structure of ID group were improved compared to those of I group (Fig. 2A). Histological morphology (villus length, crypt depth, villus width, and villus area) of jejunum deteriorated $(P<0.05)$ in I group compared to that in $\mathrm{N}$ group (Fig. 2B and Table 2). The ID group showed improvement $(P<0.05)$ in the histological morphology of their jejunum compared to that in I group (Fig. 2B, Table 2). 
Table 2

Effects of DMG-Na on jejunum morphology of IUGR weaned piglets ${ }^{1}$

\begin{tabular}{|c|c|c|c|}
\hline \multicolumn{4}{|c|}{ Treatment $^{2}$} \\
\hline Item & $\mathrm{N}$ & I & ID \\
\hline Villus length $(\mu \mathrm{m})$ & $636.77 \pm 7.98^{a}$ & $568.38 \pm 7.15^{c}$ & $609.18 \pm 8.26^{b}$ \\
\hline Crypt depth $(\mu \mathrm{m})$ & $132.67 \pm 3.38^{\mathrm{a}}$ & $110.78 \pm 2.92^{\mathrm{c}}$ & $121.85 \pm 3.65^{b}$ \\
\hline Villus width $(\mu \mathrm{m})$ & $126.66 \pm 3.52^{\mathrm{a}}$ & $108.38 \pm 4.05^{c}$ & $119.58 \pm 3.47^{b}$ \\
\hline Villus area $\left(\mathrm{mm}^{2}\right)$ & $0.127 \pm 0.008^{a}$ & $0.097 \pm 0.007^{c}$ & $0.115 \pm 0.006^{b}$ \\
\hline \multicolumn{4}{|c|}{$\begin{array}{l}1 \text { Values are expressed as Mean } \pm \text { SEM, } n=10 \text {. Values in the same row with different superscripts } \\
\text { were significantly different }(P<0.05) \text {. The assays were conducted in triplicate. }\end{array}$} \\
\hline \multicolumn{4}{|c|}{$\begin{array}{l}{ }^{2} \mathrm{~N} \text {, NBW weaned piglets fed with common basal diets; I, IUGR weaned piglets fed with common basa } \\
\text { diets; ID, IUGR weaned piglets fed with common basal diets plus } 0.1 \% \text { DMG-Na; NBW, normal birth } \\
\text { weight; IUGR, intrauterine growth retardation. }\end{array}$} \\
\hline
\end{tabular}

Effects of DMG-Na on serum immunoglobulin and jejunum slgA level of IUGR weaned piglets were observed in Table 3. Compared with $\mathrm{N}$ group, I group showed a decrease $(P<0.05)$ in serum IgA, IgG, and $\lg M$, and jejunum slgA levels. Serum $\lg A$, IgG, and $\lg M$, and jejunum slgA levels of ID group were all improved $(P<0.05)$ compared to those in I group. 
Table 3

Effects of DMG-Na on serum immunoglobulin and jejunum slgA level of IUGR weaned piglets ${ }^{1}$

Treatment $^{2}$

\begin{tabular}{|c|c|c|c|}
\hline \multicolumn{4}{|c|}{ Treatment $^{2}$} \\
\hline Item ${ }^{3}$ & $\mathrm{~N}$ & I & ID \\
\hline $\lg A(\mu \mathrm{g} / \mathrm{mL})$ & $12.39 \pm 0.15^{a}$ & $6.95 \pm 0.07^{c}$ & $9.77 \pm 0.09^{b}$ \\
\hline $\operatorname{lgG}(\mu \mathrm{g} / \mathrm{mL})$ & $8.54 \pm 0.08^{a}$ & $3.96 \pm 0.06^{c}$ & $6.99 \pm 0.08^{b}$ \\
\hline $\lg M(\mu \mathrm{g} / \mathrm{mL})$ & $5.78 \pm 0.07^{a}$ & $4.44 \pm 0.09^{c}$ & $5.18 \pm 0.06^{b}$ \\
\hline $\operatorname{slg} A(\mu \mathrm{mol} / \mathrm{g})$ & $18.37 \pm 0.76^{a}$ & $9.66 \pm 0.70^{c}$ & $14.48 \pm 0.62^{b}$ \\
\hline \multicolumn{4}{|c|}{$\begin{array}{l}{ }^{1} \text { Values are expressed as Mean } \pm \text { SEM, } n=10 \text {. Values in the same row with different superscripts were } \\
\text { significantly different }(P<0.05) \text {. The assays were conducted in triplicate. }\end{array}$} \\
\hline \multicolumn{4}{|c|}{$\begin{array}{l}{ }^{2} \mathrm{~N} \text {, NBW weaned piglets fed with common basal diets; I, IUGR weaned piglets fed with common basa } \\
\text { diets; ID, IUGR weaned piglets fed with common basal diets plus } 0.1 \% \text { DMG-Na; NBW, normal birth } \\
\text { weight; IUGR, intrauterine growth retardation. }\end{array}$} \\
\hline
\end{tabular}

Effects of DMG-Na on jejunum digestive enzyme activity of IUGR weaned piglets were revealed in Table 4. Intestinal digestive enzymes (Amylase, Lipase, Trypsin, Maltase, and Lactase) activity of jejunum showed a decrease $(P<0.05)$ in I group compared to those in $\mathrm{N}$ group. The ID group had an increased $(P<0.05)$ activity in their jejunum digestive enzymes (Amylase, Lipase, Trypsin, Maltase, and Lactase) compared to that in I group. 
Table 4

Effects of DMG-Na on jejunum digestive enzyme activity of IUGR weaned piglets ${ }^{1}$

\begin{tabular}{|llll|}
\hline \multicolumn{4}{|l|}{ Treatment $^{2}$} \\
\hline Item (U/mg protein) & $\mathrm{N}$ & $\mathrm{I}$ & ID \\
\hline Amylase & $6.28 \pm 0.08^{\mathrm{a}}$ & $2.51 \pm 0.03^{\mathrm{c}}$ & $5.05 \pm 0.03^{\mathrm{b}}$ \\
\hline Lipase & $0.25 \pm 0.01^{\mathrm{a}}$ & $0.07 \pm 0.01^{\mathrm{c}}$ & $0.18 \pm 0.01^{\mathrm{b}}$ \\
\hline Trypsin & $0.52 \pm 0.03^{\mathrm{a}}$ & $0.20 \pm 0.01^{\mathrm{c}}$ & $0.42 \pm 0.01^{\mathrm{b}}$ \\
\hline Sucrase & $73.58 \pm 4.41$ & $68.71 \pm 3.52$ & $70.82 \pm 4.03$ \\
\hline Maltase & $388.82 \pm 6.98^{\mathrm{a}}$ & $287.46 \pm 5.18^{\mathrm{c}}$ & $358.83 \pm 6.26^{\mathrm{b}}$ \\
\hline Lactase & $147.98 \pm 1.71^{\mathrm{a}}$ & $86.20 \pm 1.99^{\mathrm{c}}$ & $121.74 \pm 1.83^{\mathrm{b}}$ \\
\hline
\end{tabular}

${ }^{1}$ Values are expressed as Mean $\pm S E M, n=10$. Values in the same row with different superscripts were significantly different $(P<0.05)$. The assays were conducted in triplicate.

${ }^{2} \mathrm{~N}$, NBW weaned piglets fed with common basal diets; I, IUGR weaned piglets fed with common basal diets; ID, IUGR weaned piglets fed with common basal diets plus $0.1 \%$ DMG-Na; NBW, normal birth weight; IUGR, intrauterine growth retardation.

Effects of DMG-Na on the redox status, such as SOD, GSH-Px, GSH, GR, CAT, and MDA, of serum and jejunum in IUGR weaned piglets were presented in Table 5 and Table 6 . I group showed a lower $(P<0.05)$ antioxidant capacity and higher $(P<0.05)$ MDA concentration in serum and jejunum with respect to the values for these in $\mathrm{N}$ group. The ID group showed an increased $(P<0.05)$ antioxidant capacity and decreased $(P<0.05)$ MDA content in serum and jejunum compared to that in I group. 
Table 5

Effects of DMG-Na on serum redox status of IUGR weaned piglets ${ }^{1}$

\begin{tabular}{|c|c|c|c|}
\hline \multicolumn{4}{|c|}{ Treatment $^{2}$} \\
\hline Item ${ }^{3}$ & $\mathrm{~N}$ & I & ID \\
\hline $\mathrm{SOD}(\mathrm{U} / \mathrm{mL})$ & $143.49 \pm 5.68^{a}$ & $118.57 \pm 7.10^{b}$ & $133.79 \pm 6.22^{\mathrm{a}}$ \\
\hline GSH-Px (U/mL) & $356.77 \pm 7.96^{a}$ & $246.72 \pm 7.11^{c}$ & $300.28 \pm 8.08^{b}$ \\
\hline $\mathrm{GSH}(\mathrm{U} / \mathrm{mL})$ & $49.76 \pm 1.77^{a}$ & $23.54 \pm 1.14^{c}$ & $36.48 \pm 1.18^{b}$ \\
\hline $\mathrm{GR}(\mathrm{U} / \mathrm{mL})$ & $9.97 \pm 0.10^{a}$ & $3.19 \pm 0.06^{c}$ & $6.58 \pm 0.06^{b}$ \\
\hline CAT $(\mathrm{U} / \mathrm{mL})$ & $2.56 \pm 0.05^{a}$ & $0.68 \pm 0.02^{c}$ & $1.79 \pm 0.05^{b}$ \\
\hline $\mathrm{MDA}(\mathrm{nmol} / \mathrm{mL})$ & $4.96 \pm 0.08^{b}$ & $7.50 \pm 0.05^{a}$ & $5.33 \pm 0.03^{b}$ \\
\hline \multicolumn{4}{|c|}{$\begin{array}{l}{ }^{1} \text { Values are expressed as Mean } \pm \text { SEM, } n=10 \text {. Values in the same row with different superscripts were } \\
\text { significantly different }(P<0.05) \text {. The assays were conducted in triplicate. }\end{array}$} \\
\hline \multicolumn{4}{|c|}{$\begin{array}{l}{ }^{2} \mathrm{~N} \text {, NBW weaned piglets fed with common basal diets; I, IUGR weaned piglets fed with common basa } \\
\text { diets; ID, IUGR weaned piglets fed with common basal diets plus } 0.1 \% \text { DMG-Na; NBW, normal birth } \\
\text { weight; IUGR, intrauterine growth retardation. }\end{array}$} \\
\hline
\end{tabular}


Table 6

Effects of DMG-Na on jejunum redox status of IUGR weaned piglets ${ }^{1}$

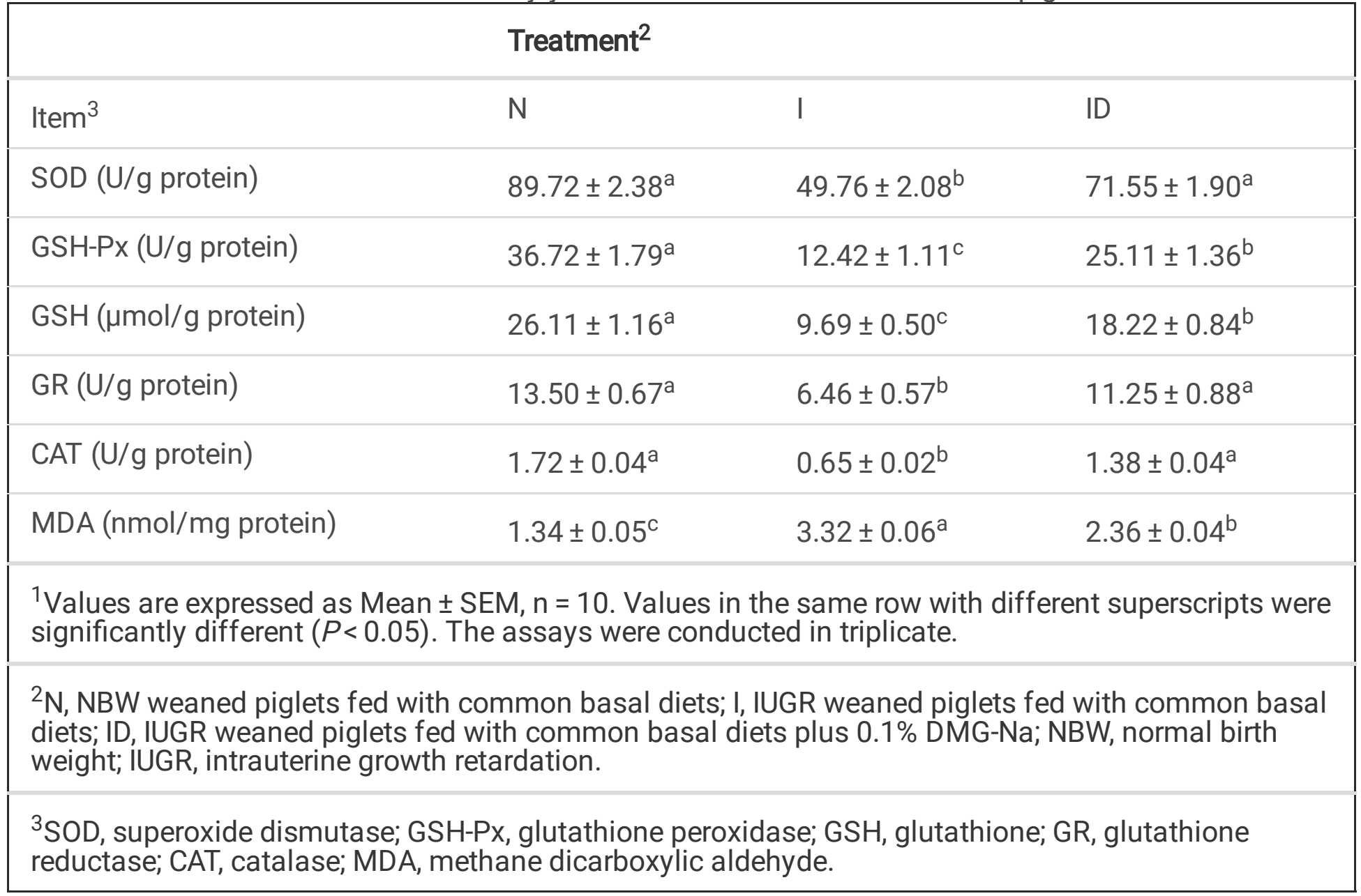

Effects of DMG-Na on jejunum mitochondrial MnSOD, GPx, GSH, GR, and $\mathrm{Y}$-GCL activity of IUGR weaned piglets were shown in Table 7. It was indicated that I group showed a lower $(P<0.05)$ level of jejunum mitochondrial MnSOD, GPx, GSH, GR, and $\mathrm{y}-\mathrm{GCL}$ with respect to their levels in $\mathrm{N}$ group. Compared to I group, ID group showed higher $(P<0.05)$ levels of jejunum mitochondrial MnSOD, GPx, GSH, GR, and $\mathrm{Y}^{-}$ GCL. 
Table 7

Effects of DMG-Na on jejunum mitochondrial redox status of IUGR weaned piglets ${ }^{1}$

\begin{tabular}{|c|c|c|c|}
\hline \multicolumn{4}{|c|}{ Treatment $^{2}$} \\
\hline Item ${ }^{3}$ & $\mathrm{~N}$ & I & ID \\
\hline MnSOD (U/mg protein) & $72.28 \pm 2.54^{\mathrm{a}}$ & $44.49 \pm 2.09^{c}$ & $66.83 \pm 2.11^{\mathrm{b}}$ \\
\hline GPx (U/mg protein) & $18.54 \pm 0.66^{a}$ & $6.56 \pm 0.08^{c}$ & $11.49 \pm 0.12^{b}$ \\
\hline GSH ( $\mu \mathrm{g} / \mathrm{g}$ protein) & $19.63 \pm 0.81^{a}$ & $7.41 \pm 0.08^{c}$ & $15.02 \pm 0.15^{\mathrm{b}}$ \\
\hline GR (U/mg protein) & $7.78 \pm 0.07^{a}$ & $3.11 \pm 0.05^{\mathrm{b}}$ & $6.25 \pm 0.04^{a}$ \\
\hline y-GCL (U/mg protein) & $2.28 \pm 0.03^{\mathrm{a}}$ & $1.23 \pm 0.06^{b}$ & $1.88 \pm 0.05^{a}$ \\
\hline \multicolumn{4}{|c|}{$\begin{array}{l}{ }^{1} \text { Values are expressed as Mean } \pm \text { SEM, } n=10 \text {. Values in the same row with different superscripts were } \\
\text { significantly different }(P<0.05) \text {. The assays were conducted in triplicate. }\end{array}$} \\
\hline \multicolumn{4}{|c|}{$\begin{array}{l}{ }^{2} \mathrm{~N} \text {, NBW weaned piglets fed with common basal diets; I, IUGR weaned piglets fed with common basa } \\
\text { diets; ID, IUGR weaned piglets fed with common basal diets plus } 0.1 \% \text { DMG-Na; NBW, normal birth } \\
\text { weight; IUGR, intrauterine growth retardation. }\end{array}$} \\
\hline $\begin{array}{l}{ }^{3} \mathrm{MnSOD} \text {, manganese s } \\
\text { glutathione reductase; }\end{array}$ & $\begin{array}{l}\text { nutase; GPx, c } \\
\text { mylcysteine lic }\end{array}$ & e peroxidase; & Itathione; GR, \\
\hline
\end{tabular}

Effects of DMG-Na on jejunum oxidative damage, including ROS, PC, 8-OHdG, apoptotic, necrotic, MMP, ATP, and mtDNA level of IUGR weaned piglets were revealed in Table 8. Compared to $\mathrm{N}$ group, higher $(P<$ $0.05)$ levels of ROS, PC, 8-OHdG, apoptotic, and necrotic, and lower $(P<0.05)$ level of MMP, ATP, and mtDNA were observed in I group. Decreased $(P<0.05)$ levels of ROS, PC, 8-OHdG, apoptotic, and necrotic, and increased $(P<0.05)$ levels of MMP, ATP, and mtDNA were observed in ID group compared to the respective values in I group. 
Table 8

Effects of DMG-Na on jejunum oxidative damage of IUGR weaned piglets ${ }^{1}$

\begin{tabular}{|c|c|c|c|}
\hline & Treatment $^{2}$ & & \\
\hline Item ${ }^{3}$ & $\mathrm{~N}$ & I & ID \\
\hline ROS $(\%$, over N) & $1.00 \pm 0.03^{\mathrm{c}}$ & $3.77 \pm 0.07^{a}$ & $2.09 \pm 0.07^{b}$ \\
\hline PC $(\%$, over $N)$ & $1.00 \pm 0.04^{c}$ & $3.48 \pm 0.08^{a}$ & $2.06 \pm 0.05^{b}$ \\
\hline 8-OHdG (\%, over N) & $1.00 \pm 0.03^{c}$ & $3.20 \pm 0.03^{\mathrm{a}}$ & $1.96 \pm 0.02^{b}$ \\
\hline MMP $(\%$, over $\mathrm{N})$ & $1.00 \pm 0.05^{a}$ & $0.53 \pm 0.02^{b}$ & $0.89 \pm 0.02^{\mathrm{a}}$ \\
\hline Apoptosis cells (\%, over N) & $1.00 \pm 0.02^{\mathrm{c}}$ & $3.97 \pm 0.09^{a}$ & $2.05 \pm 0.05^{b}$ \\
\hline Necrotic cells $(\%$, over $\mathrm{N})$ & $1.00 \pm 0.06^{\mathrm{c}}$ & $2.59 \pm 0.08^{a}$ & $1.43 \pm 0.60^{b}$ \\
\hline ATP $(\mu \mathrm{mol} / \mathrm{mg}$ protein) & $1.35 \pm 0.04^{\mathrm{a}}$ & $0.62 \pm 0.02^{c}$ & $1.12 \pm 0.02^{\mathrm{a}}$ \\
\hline mtDNA $(\%$, over $N)$ & $1.00 \pm 0.06^{a}$ & $0.51 \pm 0.01^{b}$ & $0.89 \pm 0.01^{\mathrm{a}}$ \\
\hline
\end{tabular}

${ }^{1}$ Values are expressed as Mean \pm SEM, $n=10$. Values in the same row with different superscripts were significantly different $(P<0.05)$. The assays were conducted in triplicate.

${ }^{2} \mathrm{~N}$, NBW weaned piglets fed with common basal diets; I, IUGR weaned piglets fed with common basal diets; ID, IUGR weaned piglets fed with common basal diets plus $0.1 \%$ DMG-Na; NBW, normal birth weight; IUGR, intrauterine growth retardation.

${ }^{3} \mathrm{ROS}$, reactive oxygen species; PC, protein carbonyls; 8-OHdG, 8-hydroxy-2- deoxyguanosine; MMP, mitochondrial membrane potential; ATP, adenosine triphosphate; mtDNA, mitochondria DNA.

Effects of DMG-Na on jejunum redox status-related gene expression and mitochondrial function-related gene expression level of IUGR weaned piglets were presented in Fig. 4. The redox status-related gene expression (Nrf2, HO1, Cu/ZnSOD, GSH-Px, MnSOD, y-GCLC, y-GCLm, Trx2, Trx-R2, Prx3, Sirt1, PGC1a, $O C L N, C L D N 2, C L D N 3, Z O 1)$ (Fig. 4A) and mitochondrial function-related gene expression (ATP8, MCD, MCAD, SDH, UCP2, COX2, CS, COX1, Cyt C, ERRa, MHC1, mtTFA, Ndufa2, NRF1, UCP1, POLG1, POLG2, SSBP1, Drp1, Fis1, Mfn2) (Fig. 4B and Fig. 4C) level of jejunum deteriorated $(P<0.05)$ in I group compared to those in $\mathrm{N}$ group. Compared to I group, redox status-related gene expression and mitochondrial function-related gene expression level of jejunum was improved $(P<0.05)$ in ID group.

Effects of DMG-Na on jejunum redox status-related protein content (Nrf2, HO1, SOD, GSH-Px, Sirt1, and PGC1a) and mitochondrial function-related protein content (Cyt C, ERRa, mtTFA, NRF1, Mfn2, Drp1, and Fis1) of IUGR weaned piglets were presented in Fig. 5. Compared to N group, I group showed a lower $(P<$ 0.05) level of SOD, GSH-Px, Sirt1, Cyt C, ERRa, mtTFA, NRF1, Mfn2, Drp1, and Fis1, along with a higher ( $P$ $<0.05)$ level of Nrf2, H01, and PGC1a. The ID group presented a higher $(P<0.05)$ level of SOD, GSH-Px, 
Sirt1, Cyt C, ERRa, mtTFA, NRF1, Mfn2, Drp1, and Fis1, and lower $(P<0.05)$ level of Nrf2, HO1, and PGC1a compared to those in I group.

\section{Discussion}

IUGR has received more attention from animal husbandry for its irreversible oxidative damage, delayed postnatal growth, and intestinal health $[1,12,27]$. Several studies used IUGR weaned piglets as a model to exhibit its poor performance [28,29], and these outcomes agree with our results, which demonstrate that the IUGR group exerts lower growth performance compared to the NBW group. As expected, supplemented with DMG-Na could improve the growth performance of IUGR weaned piglets, which might be explained based on its high radicals scavenging capacity and benefits on intestinal health [30]. However, the effects of DMG-Na on improving the growth performance of IUGR weaned piglets remain to be further studied.

The small intestine is crucial in nutrient digestion, absorption, and metabolism. IUGR leads to intestinal diseases in the perinatal period and makes individuals prone to feeding intolerance and digestive diseases in the early postnatal period [31]. The movement of substances across the cell membrane depends on diffusion or active transport that is regulated by intestinal structure [32]. From the RNA-seq and WGCNA analysis in this work, we found ATP8 was the most significantly changed gene in jejunum between NBW and IUGR group that involved in maintaining mitochondrial function [33]. Thus, we hypothesis that the jejunum dysfunction in IUGR piglets might be related to the alteration of its mitochondrial function. Consistent with our results, studies indicated that IUGR leads to intestinal villus atrophy, mucosal oxidative damage, and intestinal dysfunction, thereby causing diarrhea and reduction of feed utilization in piglets [34,35]. This study also showed that autophagosomes and mitochondrial swelling appeared in the small intestine of the IUGR group, which may relate to their malnutrition in the uterus and is likely to be alleviated by replenishment of acquired nutrients [36]. A previous study suggested that DMG-Na acted as an antioxidant, protecting the small intestine from oxidative damage, maintaining its normal histological morphology [37]. Another study found that DMG-Na exerted a positive effect on cell protection from oxidative damage [38], and this might be one possible reason for the results seen in the histological analysis.

IUGR is a serious complication of the mammalian fetus during pregnancy, which limits fetal development and impair their immune function during the perinatal period. IgA, IgG, and IgM levels in the body are important because these reflect the immune status and their capacity of fighting against various infections. The IgA could turn to slgA in cell gaps with secreted fragments produced by epithelial cells and then bind to the corresponding antigen in order to protect the intestine from oxidative damage [39]. It has been suggested that IUGR can damage the small intestine in piglets and lead to abnormalities in intestinal morphology and immune function [40]. DMG-Na increases serum immunoglobulin levels through its immunomodulatory function, which might represent one possible explanation for the results in this study [11]. 
Small intestinal digestive enzymes, cytokines, and immunoglobulins are related to its growth and immune function and have a role to prevent bacterial invasion. Consistent with our results, studies suggested that intestinal growth of IUGR weaned piglets is blocked, causing digestive enzyme secretion abnormalities, which may closely relate to intestinal epithelial cell apoptosis and proliferation imbalance and would lead to seriously affect the digestion and utilization of diets [41, 42]. After adding 0.1\% DMG$\mathrm{Na}$ to the diet, results suggested that DMG-Na may improve the digestion and absorption of nutrients in the IUGR group because of its capacity of protecting the intestine from oxidative damage.

Oxidative damage could enhance the ROS level, decrease antioxidant capacity, and destroy the mitochondrial structure. Mitochondrial swelling of the IUGR group in the current study suggest a destroyed redox status of the small intestine [43]. Oxidative damage could be improved by the SOD enzyme, which catalyzes the conversion of endogenous superoxide anions to hydrogen peroxide through disproportionation, and finally neutralized by intracellular enzyme GSH-Px [44]. Meanwhile, MnSOD enzyme, GSH-related metabolic enzymes, and $\mathrm{Y}$-GCL enzyme are crucial in suppressing oxidative damage in mitochondria $[45,46]$. A previous study found that DMG-Na could act as an antioxidant additive to improve body antioxidant capacity [30,37]. After adding 0.1\% DMG-Na to the diet, these results suggested that DMG-Na could improve the antioxidant capacity through scavenging ROS generated excessively, so as to maintain the balance of the intracellular redox status.

The ROS level in cells maintains a dynamic balance with the antioxidant system. However, this balance will be disturbed if subjected to some environmentally-induced conditions, finally resulting in oxidative damage [47]. Excessive ROS could induce mitochondria and DNA structural damage, ultimately affecting antioxidant capacity $[48,49]$. IUGR is closely related to oxidative damage, mitochondrial dysfunction, high ROS level, and even the occurrence of metabolic syndrome [50]. From the RNA-seq and WGCNA analysis in this study, we found ATP8 was the most significantly changed gene in jejunum between NBW and IUGR group that involved in ROS generation [33]. It has been suggested that excessive ROS induces mitochondrial DNA (mtDNA) damage, whereas impaired mitochondrial function and produces more endogenous ROS [51]. The MMP level, negatively associated with ROS concentration, acts as an indicator of the beginning of mitochondria-dependent apoptosis [52]. Consistent with our results, a study indicated that IUGR reduces antioxidant enzyme activity and mtDNA level of weaned piglets [53]. Another study also found that IUGR piglets have reduced antioxidant capacity and are prone to suffer from oxidative damage $[54,55]$. It can be seen from the results that the reduction of antioxidant capacity in the IUGR group leads to impaired intestinal function. These results also suggested that DMG-Na could relieve oxidative damage due to the scavenging of excessive ROS, and different studies verified that natural antioxidants could protect cells from oxidative damage $[37,56]$.

Activation of $\mathrm{Nrf} 2$ and $\mathrm{HO} 1$ is important in relieving oxidative damage by regulating antioxidant gene expression (SDO, GSH-Px, Y-GCL) [57, 58]. Mitochondria are rich in Trx2, Trx-R2, and Prx3 proteins, which act together to prevent oxidative damage by scavenging free radicals and regulating mitochondria-dependent apoptotic pathways [59]. PGC1a is a coactivator with pleiotropic functions, which could regulate mitochondrial function gene expression (COX1, Cyt C, ERRa, MHC1, mtTFA, Ndufa2, 
NRF1, NRF2, UCP1, (mtDNA replication and repair (POLG1, POLG2, SSBP1) and mitochondrial fission (Drp1, Fis1) and fusion (Mfn2)), as it induces mitochondrial genes both at the level of the nuclear and mitochondrial genome $[60,61]$. SIRT1, originally described as a factor regulating apoptosis and DNA repair, is highly sensitive to cellular redox and nutritional status and it is known to control genomic stability and cellular metabolism [62]. Previous studies reported that SIRT1 physically interacts with and deacetylates PGC1a at multiple lysine sites, consequently increasing PGC1a activity and regulating antioxidant capacity, lipid oxidation enzymes (MCD, MCAD), and mitochondrial gene expression (SDH, UCP2, COX2, CS) $[63,64]$. Z01, correlated with paracellular permeability, together with OCLN and CLDN gene families, are key regulators of intestinal permeability [65]. To our knowledge, this is the first work that showed the effects of DMG-Na on jejunum redox status and its mitochondrial function of IUGR weaned piglets via the SIRT1/PGC1a pathway, and further work is still needed on this specific mechanism.

In conclusion, the present study demonstrated that DMG-Na could effectively improve small intestinal damage of IUGR weaned piglets. We speculated that DMG-Na could directly neutralize excessive free radicals, and indirectly improve redox status and inhibit abnormal expression of stress-related factors via the SIRT1/PGC1 a network. Therefore, this suggests that DMG-Na can serve as a health-promoting substance and could be used in the field of IUGR weaned piglets disorder prevention.

\section{Abbreviations}

ADG: Average daily gain

ADFI: Average daily feed intake

ATP: Adenosine triphosphate

CAT: Catalase

CLDN2: Claudin 2

CLDN3: Claudin 3

COX1: Cytochrome c oxidase 1

COX2: Cytochrome c oxidase 2

CS: Citrate synthase

Cu/ZnSOD: $\mathrm{Cu} / \mathrm{Zn}$ superoxide dismutase

Cyt C: Cytochrome C

DMG-Na: Dimethylglycine sodium salt 
Drp1: Dynamin-related protein 1

ERRa: Estrogen-related receptor a

FBW: Final body weight

Fis1: Mitochondrial fission 1

GR: Glutathione reductase

GSH-Px: Glutathione peroxidase

GSH: Reduced glutathione

H01: Heme oxygenase 1

IBW: Initial body weight

IgA: Immunoglobulin A

IgG: Immunoglobulin G

IgM: Immunoglobulin M

IUGR: Intrauterine growth restriction

MCD: Malonyl-CoA decarboxylase

MCAD: Medium-chain acyl-CoA dehydrog-enase

MDA: Malondialdehyde

Mfn2: Mitofusin-2

MHCI: Major histocompatibility complex I

MMP: Mitochondrial membrane potential

MnSOD: Mn superoxide dismutase

mtDNA: Mitochondrial deoxyribonucleic acid

mtTFA: Mitochondrial transcription factor A

NBW: Normal birth weight

Ndufa2 NADH dehydrogenase (ubiquinone) iron-sulfur protein 2 
Nrf 1: Nuclear respiratory factor 1

Nrf2: Nuclear respiratory factor 2

OCLN: Occludin

PC: Protein carboxyls

PGC1a: Peroxisome proliferator-activated receptor gamma coactivator 1-alpha

POLG1:Y DNA polymerases catalytic subunit

POLG2:Y DNA polymerases accessory subunit

Prx3: Peroxidase 3

ROS: Reactive oxygen species

SDH: Mitochondrial proteins succinate dehydrogenase

SIRT1: Sirtuin 1

slgA: Secretory immunoglobulin A

SOD: Superoxide dismutase

SSBP1: Mitochondrial DNA single-strand binding protein

T-AOC: Total antioxidant capacity

Trx2: Thioredoxin 2

Trx-R2: Thioredoxin reductase 2

UCP1: Uncoupling protein 1

UCP2: Uncoupling protein 2

WGCNA: Weighted gene co-expression network analysis

Z01: Zonula occludens-1

8-OHdG: 8-hydroxy-2 deoxyguanosine

Y-GCL: Gamma-glutamylcysteine ligase

\section{Declarations}




\section{Ethics approval and consent to participate}

All procedures were approved by the Institutional Animal Care and Use Committee of Nanjing Agricultural University, China.

\section{Consent for publication}

Not applicable.

\section{Availability of data and materials}

The datasets produced and/or analyzed during the current study are available from the corresponding author on reasonable request.

\section{Competing interests}

No potential conflicts of interest relevant to this article were reported.

\section{Funding}

This work was supported by the National Natural Science Foundation of China [31572418]; National key research and development program of China [2018YFD0501101]; and the National Natural Science Foundation of China [31802101].

\section{Authors' contributions}

Bai Kaiwen designed and wrote the manuscript and performed most experiments. Bai Kaiwen and Jiang Luyi contributed to bioinformatics and statistical analyses. Bai Kaiwen performed some experiments and edited the manuscript. Bai Kaiwen, Li Qiming, Zhang Jingfei, Zhang Lili, and Wang Tian contributed to the design of the study and reviewed and edited the manuscript. All authors reviewed and take full responsibility for the contents of the manuscript. Bai Kaiwen is the guarantor of this work and, as such, had full access to all the data in the study and takes responsibility for the integrity of the data and the accuracy of the data analysis.

\section{Acknowledgements}

Not applicable.

\section{References}

1. Li T, Huang S, Lei L, Tao S, Xiong Y, Wu G, et al. Intrauterine growth restriction alters nutrient metabolism in the intestine of porcine offspring. J Anim Sci Biotechno. 2021;12(1):15. DOI:10.1186/s40104-020-00538-y. 
2. Dong L, Zhong X, He J, Zhang L, Bai K, Xu W, et al. Supplementation of tributyrin improves the growth and intestinal digestive and barrier functions in intrauterine growth-restricted piglets. Clin Nutr. 2016;35(2):399-407. DOI:10.1016/j.clnu.2015.03.002.

3. Zhang H, Li Y, Chen Y, Zhang L, Wang T. N-Acetylcysteine protects against intrauterine growth retardation-induced intestinal injury via restoring redox status and mitochondrial function in neonatal piglets. Eur J Nutr. 2019;58(8):3335-47. DOI:10.1007/s00394-018-1878-8.

4. Xu W, Bai K, He J, Su W, Dong L, Zhang L, et al. Leucine improves growth performance of intrauterine growth retardation piglets by modifying gene and protein expression related to protein synthesis. Nutrition. 2016;32(1):114-21. DOI:10.1016/j.nut.2015.07.003.

5. He Q, Ren P, Kong X, Xu W, Tang H, Yin Y, et al. Intrauterine growth restriction alters the metabonome of the serum and jejunum in piglets. Mol Biosyst. 2011;7(7):2147-55. DOI:10.1039/c1mb05024a.

6. Dillin A, Hsu AL, Arantes-Oliveira N, Lehrer-Graiwer J, Hsin H, Fraser AG, et al. Rates of behavior and aging specified by mitochondrial function during development. Science. 2002;298(5602):2398-401. DOI:10.1126/science.1077780.

7. Cheng K, Wang T, Li S, Song Z, Zhang H, Zhang L, et al. Effects of early resveratrol intervention on skeletal muscle mitochondrial function and redox status in neonatal piglets with or without intrauterine growth retardation. Oxid Med Cell Longev. 2020:4858975. DOI:10.1155/2020/4858975.

8. Feng C, Bai K, Wang A, Ge X, Zhao Y, Zhang L, et al. Effects of dimethylglycine sodium salt supplementation on growth performance, hepatic antioxidant capacity, and mitochondria-related gene expression in weanling piglets born with low birth weight. J Anim Sci. 2018;96(9):3791-803. DOI:10.1093/jas/sky233.

9. Friesen RW, Novak EM, Hasman D, Innis SM. Relationship of dimethylglycine, choline, and betaine with oxoproline in plasma of pregnant women and their newborn infants. J Nutr. 2007;137(12):2641-6. DOI:10.1093/jn/137.12.2641.

10. Hariganesh K, Prathiba J. Effect of dimethylglycine on gastric ulcers in rats. J Pharm Pharmacol. 2000;52(12):1519-22. DOI:10.1211/0022357001777568.

11. Levine SB, Myhre GD, Smith GL, Burns JG, Erb H. Effect of a nutritional supplement containing N, NDimethylglycine (DMG) on the racing standardbred [Horses]. Equine Pract. 1982.

12. Wang T, Huo YJ, Shi F, Xu RJ, Hutz RJ. Effects of intrauterine growth retardation on development of the gastrointestinal tract in neonatal pigs. Biol Neonate. 2005;88(1):66-72.

DOI:10.1159/000084645.

13. Mohamed JS, Lopez MA, Boriek AM. Mechanical stretch up-regulates microRNA-26a and induces human airway smooth muscle hypertrophy by suppressing glycogen synthase kinase-3 $\beta$. J Biol Chem. 2010;285(38):29336-47. DOI:10.1074/jbc.M110.101147.

14. Langfelder P, Horvath S. WGCNA: an R package for weighted correlation network analysis. BMC Bioinform. 2008;9:559. DOI:10.1186/1471-2105-9-559.

15. Chin $\mathrm{CH}$, Chen $\mathrm{SH}, \mathrm{Wu} \mathrm{HH}, \mathrm{Ho} \mathrm{CW}$, Ko MT, Lin CY. CytoHubba: identifying hub objects and subnetworks from complex interactome. BMC Syst Biol. 2014;8(Suppl 4):11. DOI:10.1186/1752-0509-8- 
s4-s11. Suppl 4 ) .

16. Yao W, Li J, Wang JJ, Zhou W, Wang Q, Zhu R, et al. Effects of dietary ratio of n-6 to n-3 polyunsaturated fatty acids on immunoglobulins, cytokines, fatty acid composition, and performance of lactating sows and suckling piglets. J Anim Sci Biotechnol. 2012;27(1):43. DOI:10.1186/2049-1891-3-43. 3 ).

17. Wan J, Zhang J, Chen D, Yu B, Mao X, Zheng P, et al. Alginate oligosaccharide-induced intestinal morphology, barrier function and epithelium apoptosis modifications have beneficial effects on the growth performance of weaned pigs. J Anim Sci Biotechnol. 2018;16:9:58. DOI:10.1186/s40104-0180273-x.

18. Mccord JM, Fridovich I. Superoxide dismutase. An enzymic function for erythrocuprein (hemocuprein). J Biol Chem. 1969;244(22):6049.

19. Paglia DE, Valentine WN. Studies on the quantitative and qualitative characterization of erythrocyte glutathione peroxidase. J Lab Clin Med. 1967;70(1):158.

20. Noctor G, Foyer $\mathrm{CH}$. Ascorbate and glutathione: keeping active oxygen under control. Annu Rev Plant Physiol Plant Mol Biol. 1998;49(49):249. DOl:10.1146/annurev.arplant.49.1.249.

21. Draper $\mathrm{HH}$, Hadley M. Malondialdehyde determination as index of lipid peroxidation. Methods Enzymol. 1990;186(186):421-31. DOI:10.1016/0076-6879(90)86135-i.

22. WE R, SC T. Method of preparing isolated colonic epithelial cells (colonocytes) for metabolic studies. Gut. 1979;20(6):484-8. DOI:10.1136/gut.20.6.484.

23. Berlett BS, Stadtman ER. Protein oxidation in aging, disease, and oxidative stress. J Biol Chem. 1997;15(33):20313-6. DOI:10.1074/jbc.272.33.20313. 272 ) .

24. Valavanidis A, Vlachogianni T, Fiotakis C. 8-hydroxy-2' -deoxyguanosine (8-OHdG): A critical biomarker of oxidative stress and carcinogenesis. J Environ Sci Health C Environ Carcinog Ecotoxicol Rev. 2009;27(2):120-39. DOI:10.1080/10590500902885684.

25. Sang H, Zhang L, Li J. Anti-benzopyrene-7,8-diol-9,10-epoxide induces apoptosis via mitochondrial pathway in human bronchiolar epithelium cells independent of the mitochondria permeability transition pore. Food Chem Toxicol. 2012;50(7):2417-23. DOl:10.1016/j.fct.2012.04.041.

26. Bai P, Cantó C, Oudart H, Brunyánszki A, Cen Y, Thomas $C$, et al. PARP-1 inhibition increases mitochondrial metabolism through SIRT1 activation. Cell Metab. 2011;6(4):461-8. DOI:10.1016/j.cmet.2011.03.004. 13 ) .

27. Garite TJ, Clark R, Thorp JA. Intrauterine growth restriction increases morbidity and mortality among premature neonates. Am J Obstet Gynecol. 2004;191(2):481-7. DOI:10.1016/j.ajog.2004.01.036.

28. Michiels J, De Vos M, Missotten J, Ovyn A, De Smet S, Van Ginneken C. Maturation of digestive function is retarded and plasma antioxidant capacity lowered in fully weaned low birth weight piglets. Br J Nutr. 2013;14(1):65-75. DOI:10.1017/S0007114512000670. 109) .

29. Zhang H, Chen Y, Li Y, Yang L, Wang J, Wang T. Medium-chain TAG attenuate hepatic oxidative damage in intrauterine growth-retarded weanling piglets by improving the metabolic efficiency of the glutathione redox cycle. Br J Nutr. 2014;28(6):876-85. DOI:10.1017/S000711451400155X. 112) . 
30. Bai K, Xu W, Zhang J, Kou T, Niu Y, Wan X, et al. Assessment of free radical scavenging activity of dimethylglycine sodium salt and its role in providing protection against lipopolysaccharide-induced oxidative stress in mice. PloS one. 2016;11(5):e0155393. DOl:10.1371/journal.pone.0155393.

31. Bernstein IM, Horbar JD, Badger GJ, Ohlsson A, Golan A. Morbidity and mortality among very-lowbirth-weight neonates with intrauterine growth restriction. The Vermont Oxford Network. Am J Obstet Gynecol. 2000;182(1 Pt 1):198-206. DOI:10.1016/s0002-9378(00)70513-8.

32. Nusrat A, Parkos CA, Verkade P, Foley CS, Liang TW, Inniswhitehouse W, et al. Tight junctions are membrane microdomains. J Cell Sci. 2000;113(Pt 10):1771-81.

33. Weiss H, Wester-Rosenloef L, Koch C, Koch F, Baltrusch S, Tiedge M, et al. The mitochondrial Atp8 mutation induces mitochondrial ROS generation, secretory dysfunction, and $\beta$-cell mass adaptation in conplastic B6-mtFVB mice. Endocrinology. 2012;153(10):4666-76. DOI:10.1210/en.2012-1296.

34. Wang T, Huo YJ, Shi F, Xu RJ, Hutz RJ. Effects of intrauterine growth retardation on development of the gastrointestinal tract in neonatal pigs. Biol Neonate. 2005;88(1):66-72.

DOI:10.1159/000084645.

35. Wang J, Chen L, Li D, Yin Y, Wang X, Li P, et al. Intrauterine growth restriction affects the proteomes of the small intestine, liver, and skeletal muscle in newborn pigs. J Nutr. 2008;138(1):60-6.

DOI:10.1093/jn/138.1.60.

36. Minamikawa T, Williams DA, Bowser DN, Nagley P. Mitochondrial permeability transition and swelling can occur reversibly without inducing cell death in intact human cells. Exp Cell Res. 1999;10(1):2637. DOI:10.1006/excr.1998.4290. 246 ) .

37. Friesen RW, Novak EM, Hasman D, Innis SM. Relationship of dimethylglycine, choline, and betaine with oxoproline in plasma of pregnant women and their newborn infants. J Nutr. 2007;137(12):2641-6. DOI:10.1093/jn/137.12.2641.

38. Look MP, Riezler R, Berthold HK, Stabler SP, Schliefer K, Allen RH, et al. Decrease of elevated N,Ndimethylglycine and $\mathrm{N}$-methylglycine in human immunodeficiency virus infection during short-term highly active antiretroviral therapy. Metabolism. 2001;50(11):1275-81.

DOI:10.1053/meta.2001.27201.

39. Brandtzaeg PE. Current understanding of gastrointestinal immunoregulation and its relation to food allergy. Ann N Y Acad Sci. 2002;964:13-45. DOl:10.1111/j.1749-6632.2002.tb04131.x.

40. Wang Y, Zhang L, Zhou G, Liao Z, Ahmad H, Liu W, et al. Dietary L-arginine supplementation improves the intestinal development through increasing mucosal Akt and mammalian target of rapamycin signals in intra-uterine growth retarded piglets. Br J Nutr. 2012;28(8):1371-81.

DOI:10.1017/S0007114511006763. 108 ).

41. Baserga M, Bertolotto C, Maclennan NK, Hsu JL, Pham T, Laksana GS, et al. Uteroplacental insufficiency decreases small intestine growth and alters apoptotic homeostasis in term intrauterine growth retarded rats. Early Hum Dev. 2004;79(2):93-105. DOI:10.1016/j.earlhumdev.2004.04.015.

42. D'Inca R, Gras-Le Guen C, Che L, Sangild PT, Le Huërou-Luron I. Intrauterine growth restriction delays feeding-induced gut adaptation in term newborn pigs. Neonatology. 2011;99(3):208-16. 
DOI:10.1159/000314919.

43. Mizushima N. Autophagy: process and function. Genes Dev. 2007;15(22):2861-73. DOI:10.1101/gad.1599207. 21 ) .

44. Bayrak O, Uz E, Bayrak R, Turgut F, Atmaca AF, Sahin S, et al. Curcumin protects against ischemia/reperfusion injury in rat kidneys. World J Urol. 2008;26(3):285-91. DOI:10.1007/s00345008-0253-4.

45. Tang Y, Gao C, Xing M, Li Y, Zhu L, Wang D, et al. Quercetin prevents ethanol-induced dyslipidemia and mitochondrial oxidative damage. Food Chem Toxicol. 2012;50(5):1194-200.

DOI:10.1016/j.fct.2012.02.008.

46. Langston JW, Li W, Harrison L, Aw TY. Activation of promoter activity of the catalytic subunit of Yglutamylcysteine ligase (GCL) in brain endothelial cells by insulin requires antioxidant response element 4 and altered glycemic status: implication for GCL expression and GSH synthesis. Free Radic Biol Med. 2011;1(9):1749-57. DOI:10.1016/j.freeradbiomed.2011.08.004. 51 ) .

47. Sun $X$, Zemel MB. Leucine modulation of mitochondrial mass and oxygen consumption in skeletal muscle cells and adipocytes. Nutr Metab (Lond). 2009;5:6:26. DOI:10.1186/1743-7075-6-26.

48. Mishra M, Panda M. Reactive oxygen species: the root cause of nanoparticle-induced toxicity in drosophila melanogaster. Free Radic Res. 2021;20:1-17. DOl:10.1080/10715762.2021.1914335.

49. Sastre J, Pallardó FV, Viña J. Mitochondrial oxidative stress plays a key role in aging and apoptosis. IUBMB Life. 2000;49(5):427-35. DOI:10.1080/152165400410281.

50. Biri A, Bozkurt N, Turp A, Kavutcu M, Himmetoglu O, Durak I. Role of oxidative stress in intrauterine growth restriction. Gynecol Obstet Invest. 2007;64(4):187-92. DOI:10.1159/000106488.

51. Simmons RA. Developmental origins of diabetes: The role of oxidative stress. Best Pract Res Clin Endocrinol Metab. 2012;26(5):701-8. DOI:10.1016/j.beem.2012.03.012.

52. Kowaltowski AJ, Vercesi AE. Mitochondrial damage induced by conditions of oxidative stress. Free Radic Biol Med. 1999 Feb;26(3-4):463-71. DOl:10.1016/s0891-5849(98)00216-0.

53. Park HK, Jin CJ, Cho YM, Park DJ, Shin CS, Park KS, et al. Changes of mitochondrial DNA content in the male offspring of protein-malnourished rats. Ann N Y Acad Sci. 2004;1011:205-16. DOI:10.1007/978-3-662-41088-2_21.

54. Biri A, Bozkurt N, Turp A, Kavutcu M, Himmetoglu O, Durak I. Role of oxidative stress in intrauterine growth restriction. Gynecol Obstet Invest. 2007;64(4):187-92. DOI:10.1159/000106488.

55. Hracsko Z, Safar Z, Orvos H, Novak Z, Pal A, Varga IS. Evaluation of oxidative stress markers after vaginal delivery or Caesarean section. In Vivo. 2007;21(4):703-6.

56. Zhang J, Xu L, Zhang L, Ying Z, Su W, Wang T. Curcumin attenuates Dgalactosamine/lipopolysaccharide-induced liver injury and mitochondrial dysfunction in mice. $J$ Nutr. 2014;144(8):1211-8. DOI:10.3945/jn.114.193573.

57. Bartel DP. MicroRNAs: genomics, biogenesis, mechanism, and function. Cell. 2004;23(2):281-97. DOI:10.1016/s0092-8674(04)00045-5. 116 ). 
58. Lim LP, Lau NC, Garrett-Engele P, Grimson A, Schelter JM, Castle J, et al. Microarray analysis shows that some microRNAs downregulate large numbers of target mRNAs. Nature. 2005;17(7027):76973. DOI:10.1038/nature03315. 433 ) .

59. Mohamed JS, Hajira A, Pardo PS, Boriek AM. MicroRNA-149 inhibits PARP-2 and promotes mitochondrial biogenesis via SIRT-1/PGC-1 a network in skeletal muscle. Diabetes. 2014;63(5):154659. DOI:10.2337/db13-1364.

60. Chiu H, Brittingham JA, Laskin DL. Differential induction of heme oxygenase-1 in macrophages and hepatocytes during acetaminophen-induced hepatotoxicity in the rat: effects of hemin and biliverdin. Toxicol Appl Pharmacol. 2002;1(2):106-15. DOl:10.1006/taap.2002.9409. 181 ) .

61. Hwang JW, Yao H, Caito S, Sundar IK, Rahman I. Redox regulation of SIRT1 in inflammation and cellular senescence. Free Radic Biol Med. 2013;61:95-110.

DOI:10.1016/j.freeradbiomed.2013.03.015.

62. Michelet L, Zaffagnini M, Massot V, Keryer E, Vanacker H, Miginiac-Maslow M, et al. Thioredoxins, glutaredoxins, and glutathionylation: new crosstalks to explore. Photosynth Res. 2006;89(2-3):22545. DOI:10.1007/s11120-006-9096-2.

63. Lin J, Handschin C, Spiegelman BM. Metabolic control through the PGC-1 family of transcription coactivators. Cell Metab. 2005;1(6):361-70. DOI:10.1016/j.cmet.2005.05.004.

64. St-Pierre J, Drori S, Uldry M, Silvaggi JM, Rhee J, Jäger S, et al. Suppression of reactive oxygen species and neurodegeneration by the PGC-1 transcriptional coactivators. Cell. 2006;20(2):397-408. DOI:10.1016/j.cell.2006.09.024. 127 ) .

65. Sinclair DA. Toward a unified theory of caloric restriction and longevity regulation. Mech Ageing Dev. 2005;126(9):987-1002. DOI:10.1016/j.mad.2005.03.019.

\section{Figures}


A

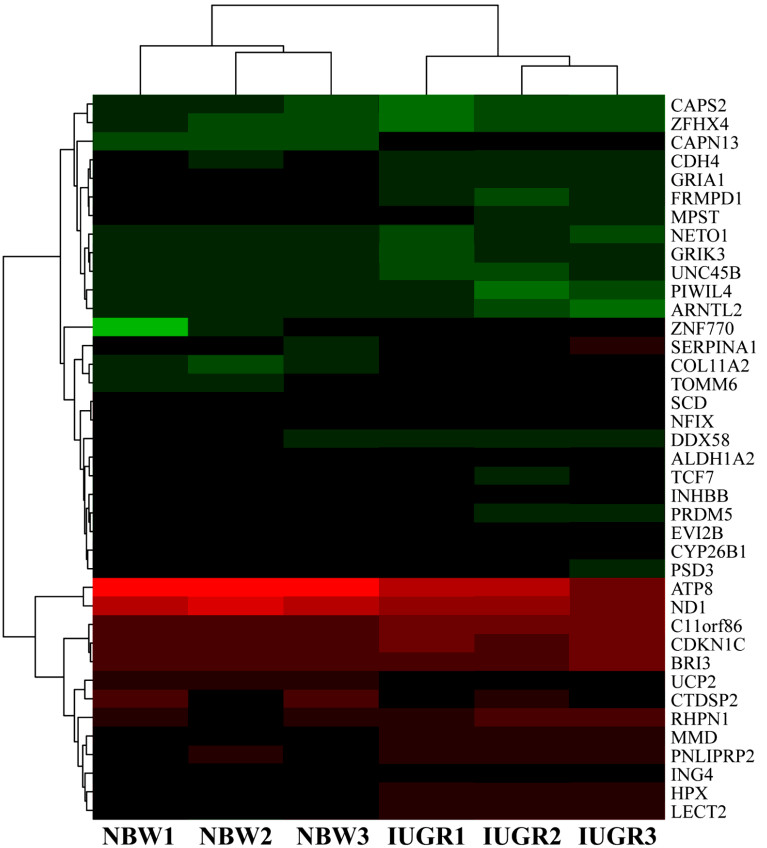

C

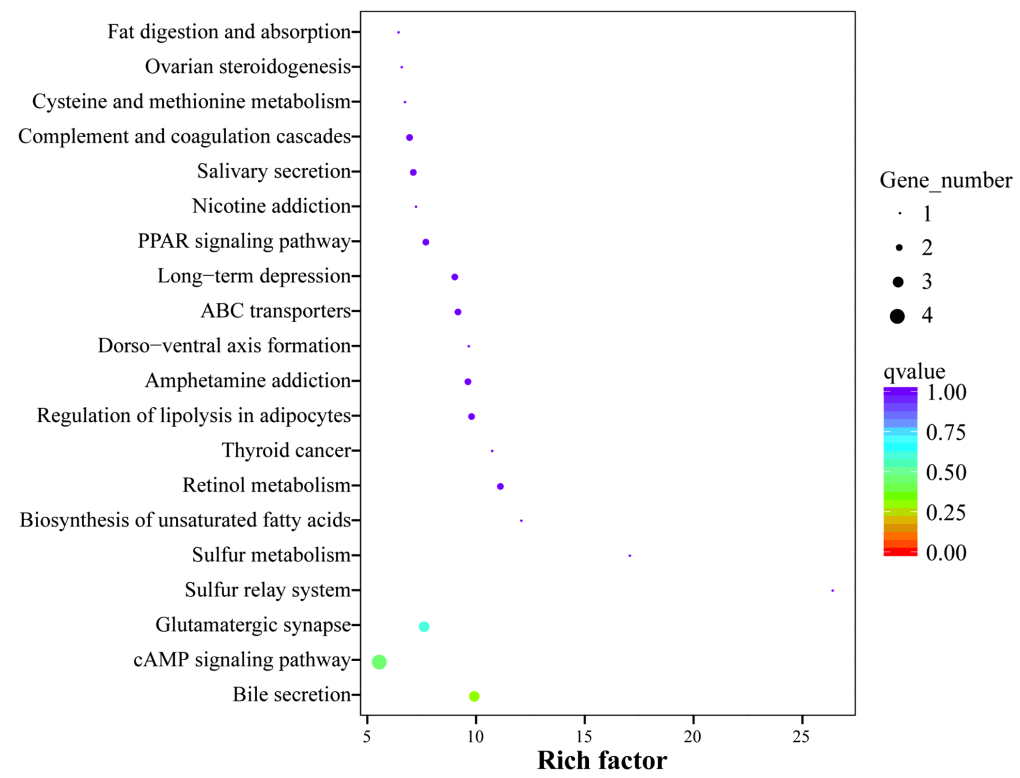

B

\begin{tabular}{|c|c|c|}
\hline MEpurple & $\begin{array}{l}-0.61 \\
(0.2)\end{array}$ & $\begin{array}{l}0.61 \\
(0.2)\end{array}$ \\
\hline MEturquoise & $\begin{array}{l}-0.42 \\
(0.4)\end{array}$ & $\begin{array}{l}0.42 \\
(0.4)\end{array}$ \\
\hline MEblue & $\begin{array}{l}0.48 \\
(0.3)\end{array}$ & $\begin{array}{c}-0.48 \\
(0.3)\end{array}$ \\
\hline MEbrown & $\begin{array}{l}0.49 \\
(0.3)\end{array}$ & $\begin{array}{l}-0.49 \\
(0.3)\end{array}$ \\
\hline MEyellow & $\begin{array}{l}0.81 \\
(0.05)\end{array}$ & $\begin{array}{l}-0.81 \\
(0.05)\end{array}$ \\
\hline MEtan & $\begin{array}{l}-0.36 \\
(0.5)\end{array}$ & $\begin{array}{l}0.36 \\
(0.5)\end{array}$ \\
\hline MEblack & $\begin{array}{l}0.51 \\
(0.3)\end{array}$ & $\begin{array}{l}-0.51 \\
(0.3)\end{array}$ \\
\hline MEgreenyellow & $\begin{array}{l}0.28 \\
(0.6)\end{array}$ & $\begin{array}{c}-0.28 \\
(0.6)\end{array}$ \\
\hline MEred & $\begin{array}{c}-0.083 \\
(0.9)\end{array}$ & $\begin{array}{l}0.083 \\
(0.9)\end{array}$ \\
\hline
\end{tabular}

\section{Figure 1}

The RNA-seq analysis of jejunum of NBW and IUGR newborn piglets. The hierarchical clustering of the different expression genes from the RNA-seq analysis $(n=3)(A)$, the KEGG pathway analyses $(n=3)(B)$, the heatmap plot between modules and traits by WGCNA analysis $(n=3)(C)$ of jejunum in NBW and IUGR newborn piglets. NBW, normal birth weight; IUGR, intrauterine growth retardation. 

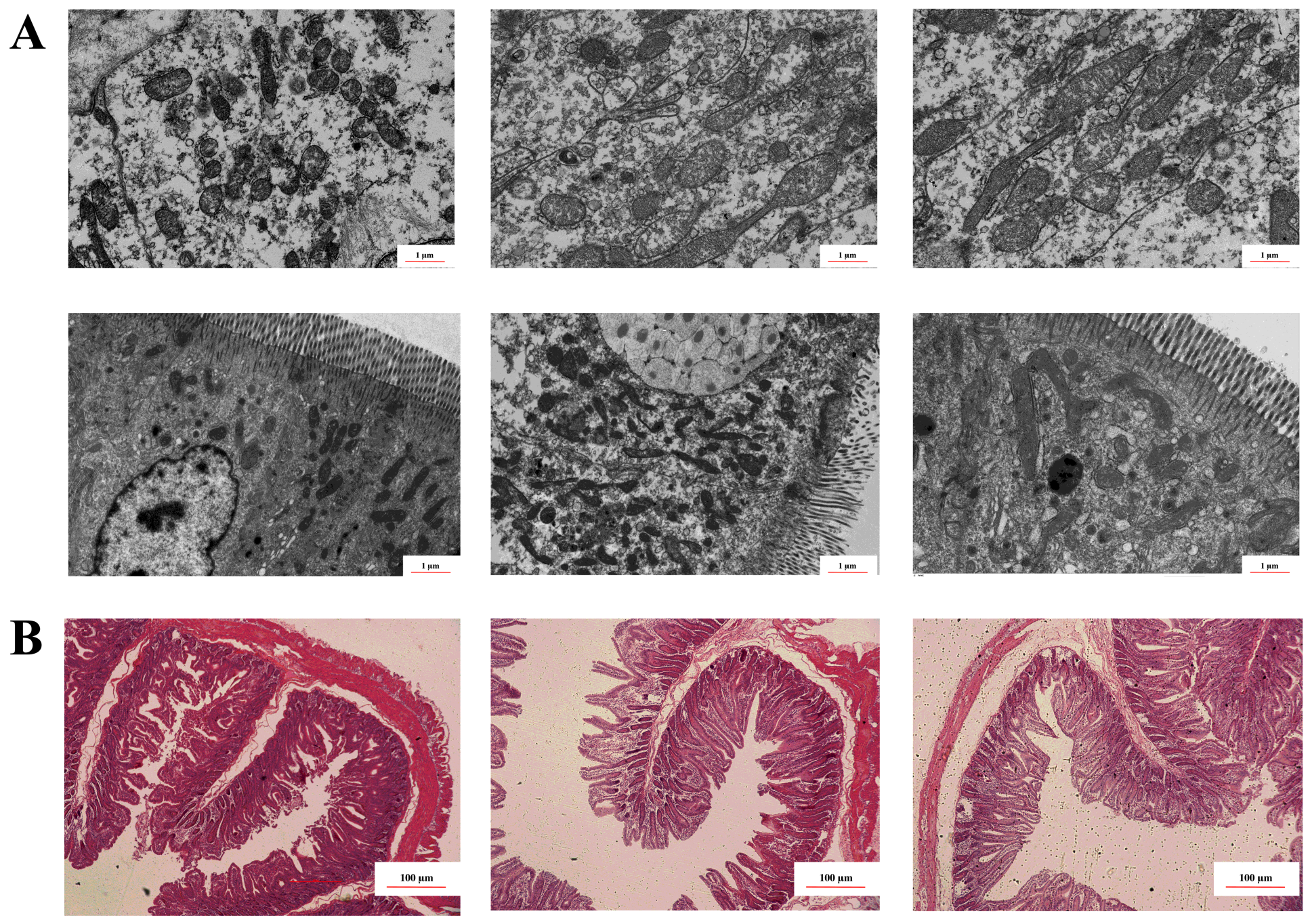

$\mathbf{N}$

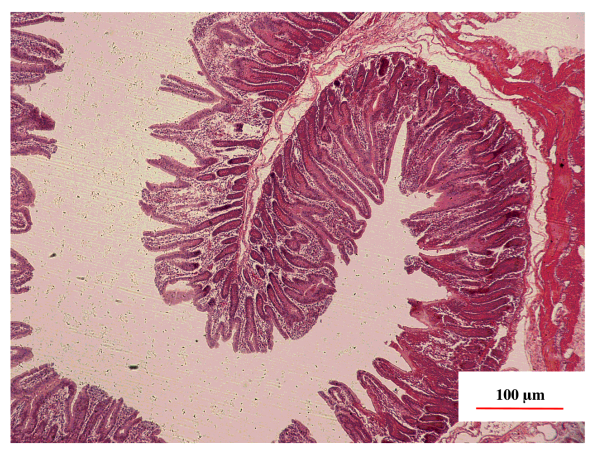

I

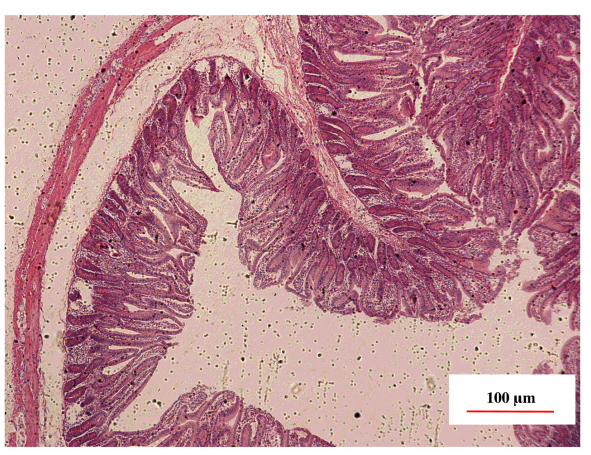

ID

\section{Figure 2}

Effects of DMG-Na on jejunum histological morphology and its sub-organelle ultrastructure of IUGR weaned piglets. Jejunum mitochondrial swelling and microvilli (A). Scale bars represent $1 \mu$ m; Jejunum histological morphology (villus length, crypt depth, villus width, and villus area) (B). Scale bars represent $100 \mu \mathrm{m}$. N, NBW weaned piglets fed with common basal diets; I, IUGR weaned piglets fed with common basal diets; ID, IUGR weaned piglets fed with common basal diets plus 0.1\% DMG-Na; NBW, normal birth weight; IUGR, intrauterine growth retardation. 

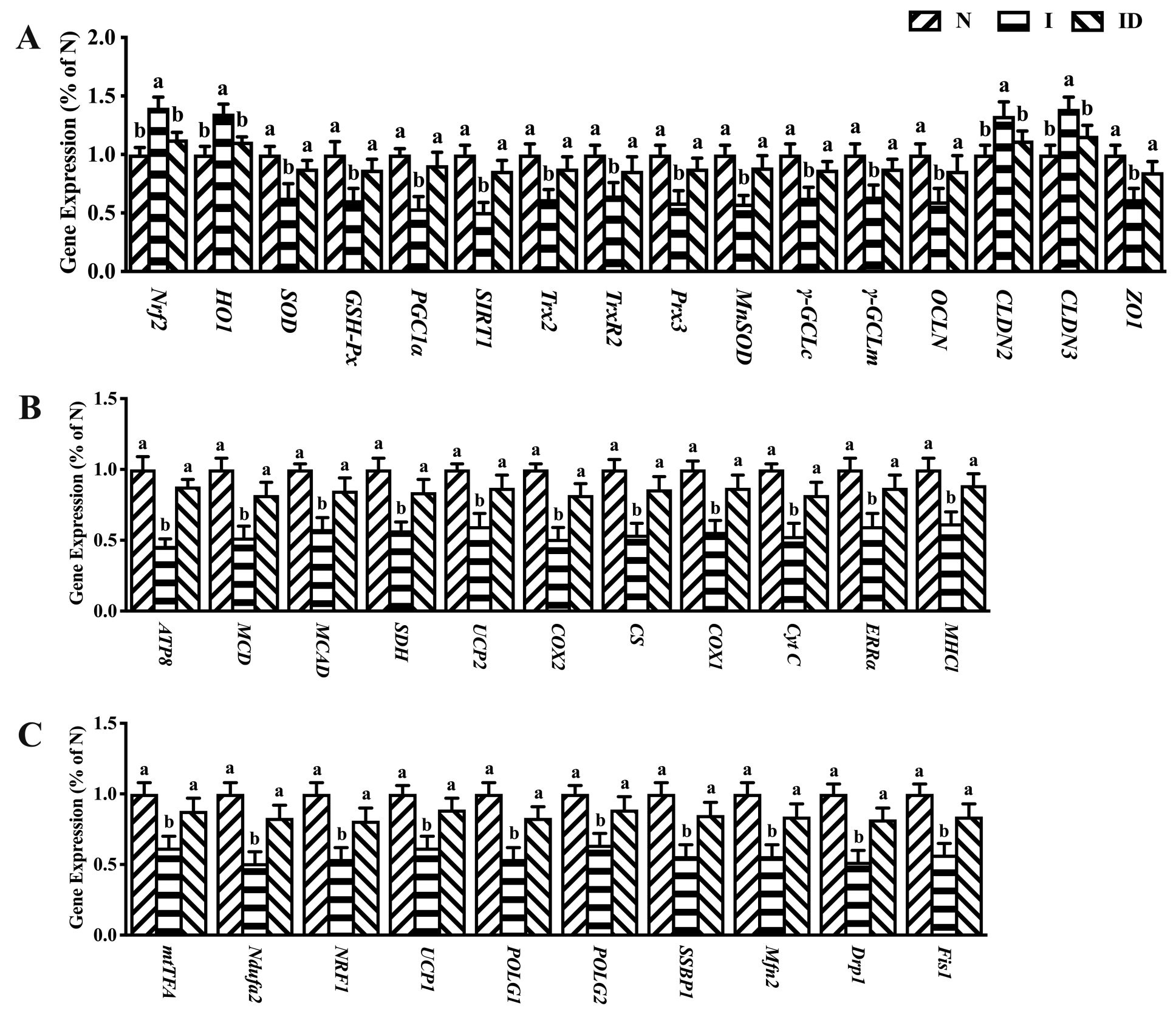

Figure 3

Effects of DMG-Na on jejunum redox status-related and mitochondrial function-related gene expression level of IUGR weaned piglets. Values are expressed as Mean $\pm S E M, n=10$. Values with different superscripts were significantly different $(P<0.05)$. The assays were conducted in triplicate. N, NBW weaned piglets fed with common basal diets; I, IUGR weaned piglets fed with common basal diets; ID, IUGR weaned piglets fed with common basal diets plus 0.1\% DMG-Na; NBW, normal birth weight; IUGR, intrauterine growth retardation; Nrf2, nuclear factor erythroid 2-related factor 2; H01, heme oxygenase 1; $\mathrm{Cu} / Z n S O D$, copper and zinc superoxide dismutase; GSH-Px, glutathione peroxidase; MnSOD, manganese superoxide dismutase; $y$-GCLc, y-glutamylcysteine ligase c; $y$-GCLm, y-glutamylcysteine ligase m; Trx2, thioredoxin 2; Trx-R2, thioredoxin reductase 2; Prx3, peroxiredoxin 3; Sirt1, sirtuin 1; PGC1a, peroxisome proliferator-activated receptorycoactivator-1a; OCLN, occluding; CLDN2, cloudin2; CLDN3, cloudin3; ZO1, 
zonula occludens-1; ATP8, mitochondrially Encoded ATP Synthase Membrane Subunit 8; MCD, lipid oxidation enzymes malonyl-CoA decarboxylase; MCAD, medium-chain acyl-CoA dehydrogenase; SDH, mitochondrial proteins succinate dehydrogenase; UCP2, uncoupling protein 2; COX2, cyclooxygenase 2; CS, citrate synthase; COX1, cyclooxygenase 1; Cyt C, Cytochrome C; ERRa, estrogen-related receptor a; $\mathrm{MHC1}$, major histocompatibility complex I; mtTFA, mitochondrial transcription factor A; Ndufa2, NADH dehydrogenase (ubiquinone) iron-sulfur protein 2; NRF1, nuclear respiratory factor 1; UCP1, uncoupling protein 1; POLG1, y DNA polymerases catalytic subunit; POLG2, y DNA polymerases accessory subunit; SSBP1, single-strand DNA binding protein 1; Drp1, dynamin-related protein 1; Fis1, mitochondrial fission 1; Mfn2, mitochondrial mitofusin2. 

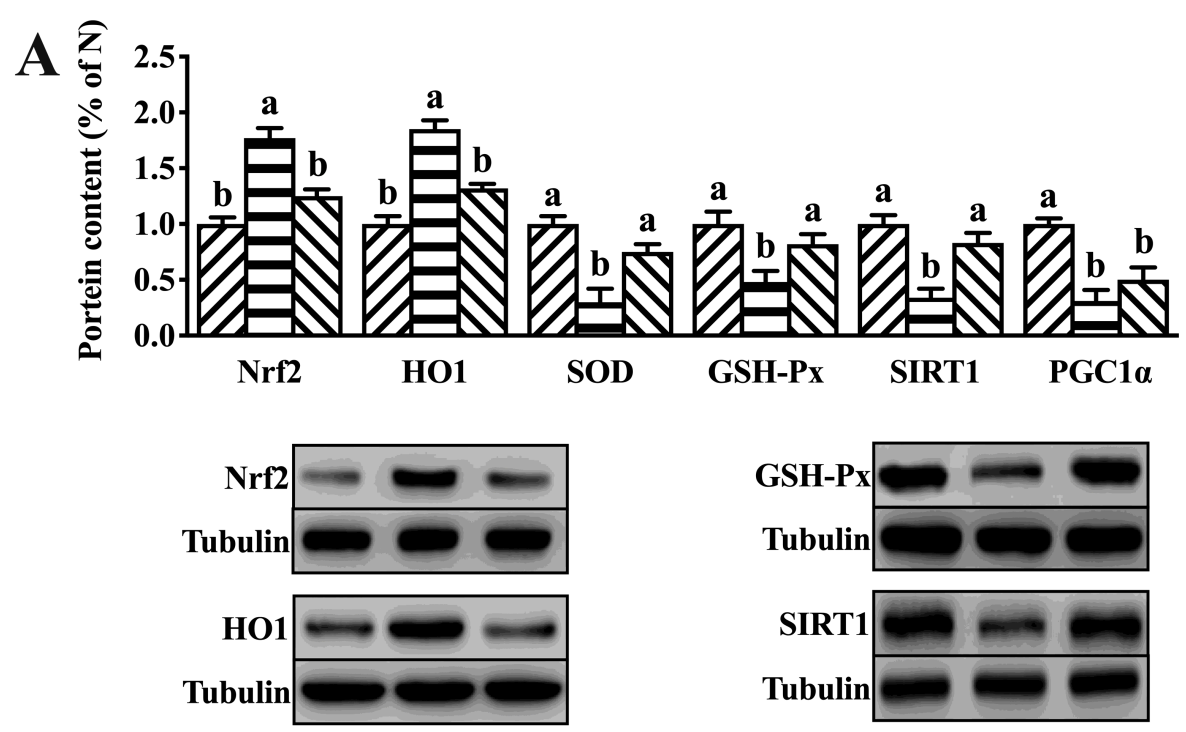

Tubulin
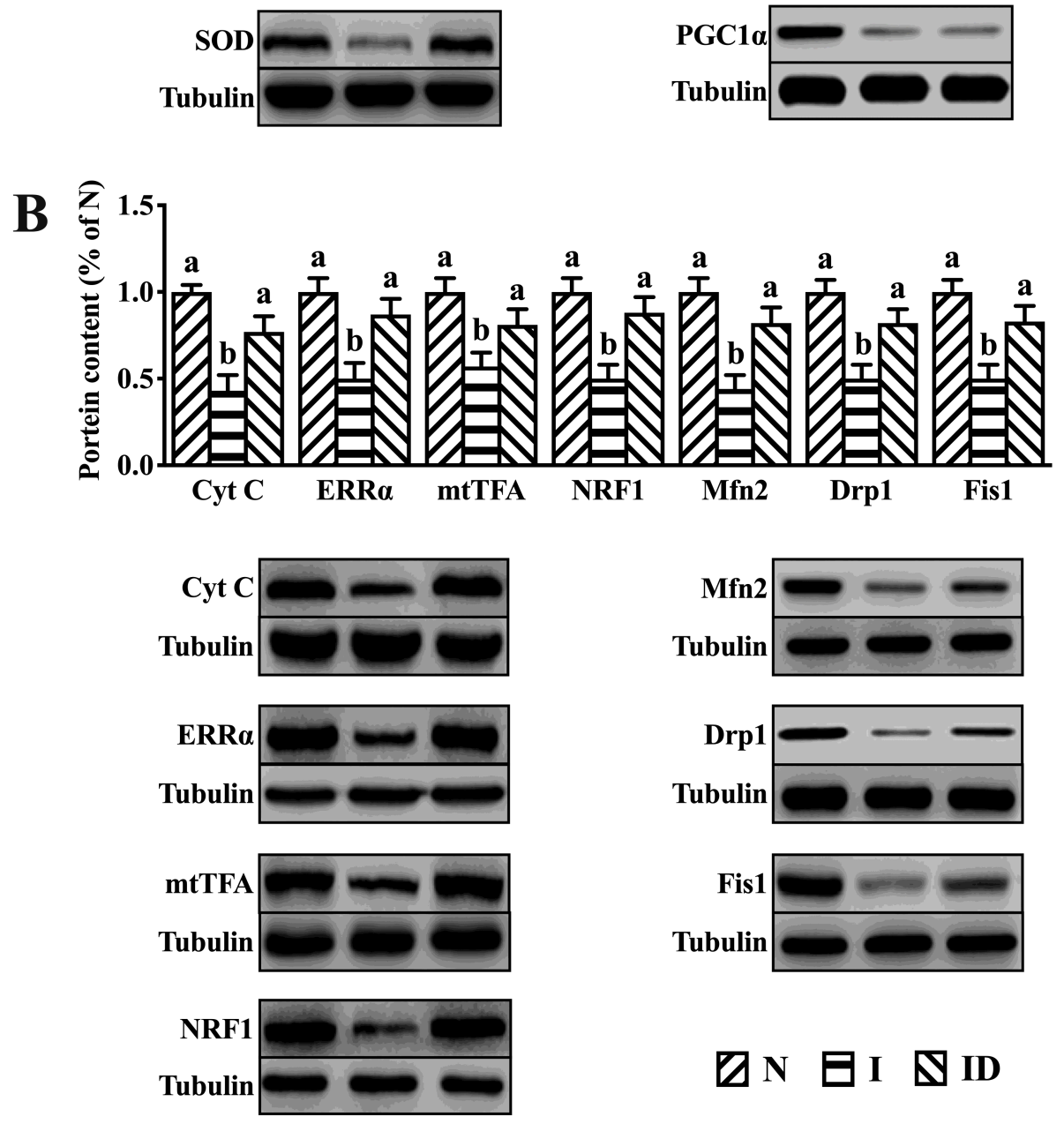

\section{Figure 4}

Effects of DMG-Na on jejunum redox status-related and mitochondrial function-related protein content of IUGR weaned piglets. Values are expressed as Mean $\pm S E M, n=10$. Values with different superscripts were significantly different $(P<0.05)$. The assays were conducted in triplicate. $N$, NBW weaned piglets fed with common basal diets; I, IUGR weaned piglets fed with common basal diets; ID, IUGR weaned piglets fed with common basal diets plus 0.1\% DMG-Na; NBW, normal birth weight; IUGR, intrauterine 
growth retardation; Nrf2, nuclear factor erythroid 2-related factor 2; HO1, heme oxygenase 1; SOD, superoxide dismutase; GSH-Px, glutathione peroxidase; Sirt1, sirtuin 1; PGC1a, peroxisome proliferatoractivated receptorycoactivator-1a; Cyt C, Cytochrome C; ERRa, estrogen-related receptor a; mtTFA, mitochondrial transcription factor A; NRF1, nuclear respiratory factor 1; Mfn2, mitochondrial mitofusin2; Drp1, dynamin-related protein 1; Fis1, mitochondrial fission 1.

\section{Supplementary Files}

This is a list of supplementary files associated with this preprint. Click to download.

- Supplementaryinformation.docx 